Maurer School of Law: Indiana University

Digital Repository @ Maurer Law

\title{
Flattening the World of Legal Services? The Ethical and Liability Minefields of Offshoring Legal and Law-Related Services
}

Carole Silver

Indiana University Maurer School of Law, c-silver@law.northwestern.edu

Mary C. Daly

St. John's University School of Law

Follow this and additional works at: https://www.repository.law.indiana.edu/facpub

Part of the International Law Commons, and the Legal Profession Commons

\section{Recommended Citation}

Silver, Carole and Daly, Mary C., "Flattening the World of Legal Services? The Ethical and Liability Minefields of Offshoring Legal and Law-Related Services" (2007). Articles by Maurer Faculty. 484.

https://www.repository.law.indiana.edu/facpub/484

This Article is brought to you for free and open access by the Faculty Scholarship at Digital Repository @ Maurer Law. It has been accepted for inclusion in Articles by Maurer Faculty by an authorized administrator of Digital Repository@ Maurer Law. For more information, please contact rvaughan@indiana.edu. 


\title{
FLATTENING THE WORLD OF LEGAL SERVICES? THE ETHICAL AND LIABILITY MINEFIELDS OF OFFSHORING LEGAL AND LAW-RELATED SERVICES
}

\author{
Mary C. Daly* \& Carole Silver ${ }^{\dagger}$
}

This article examines offshore outsourcing of legal and law-related services as the newest twist in the international market for legal services. We consider the impact of offshore outsourcing on the profession generally and analyze the ethical issues raised by offshore outsourcing, both as it exists today and as the practice may develop in the future. The article begins by situating offshore outsourcing in the framework of relationships created in the delivery of legal services. This framework is used, in turn, to construct a structure of analysis for the ethical implications of offshore outsourcing. Lawyers who outsource to offshore providers must conduct an investigation to ensure that the referral is appropriate. We consider the potential reputation and economic benefits and risks to law firms and legal departments in outsourcing offshore. We find that offshore outsourcing creates new opportunities for non-U.S. lawyers without putting them on equal footing with lawyers trained and licensed in the U.S. Instead, as with many aspects of globalization, offshore outsourcing perpetuates the divisions already present in the legal profession.

\section{INTRODUCTION}

Globalization recently has been described by Thomas Friedman as "flattening" the world through a combination of technology and "geoeconomics," resulting in a shift in the way work is accomplished and enabling new collaboration and competition. Technology enables the proliferation of information, and facilitates the division and distribution of tasks to those able to most efficiently accomplish them regardless of their location. As a result, individuals and organizations

* Dean and John V. Brennan Professor of Law and Ethics, St. John's University School of Law; J.D., 1972, Fordham University School of Law; LL.M., 1978, New York University School of Law. Dean Daly would like to express her deep appreciation to Ms. Barbara Traub, Head of Reference Services, St. John's University School of Law, for her invaluable assistance in locating primary and secondary resources about the offshoring of legal and law-related services.

+ Senior Lecturer, Northwestern University School of Law. Many thanks to Johana Gomez for valuable research assistance and comments. A portion of this paper was presented at the International Law Association's International Law Weekend in New York (October 2004), and I received helpful comments from the participants. () 2007, Mary C. Daly and Carole Silver. 


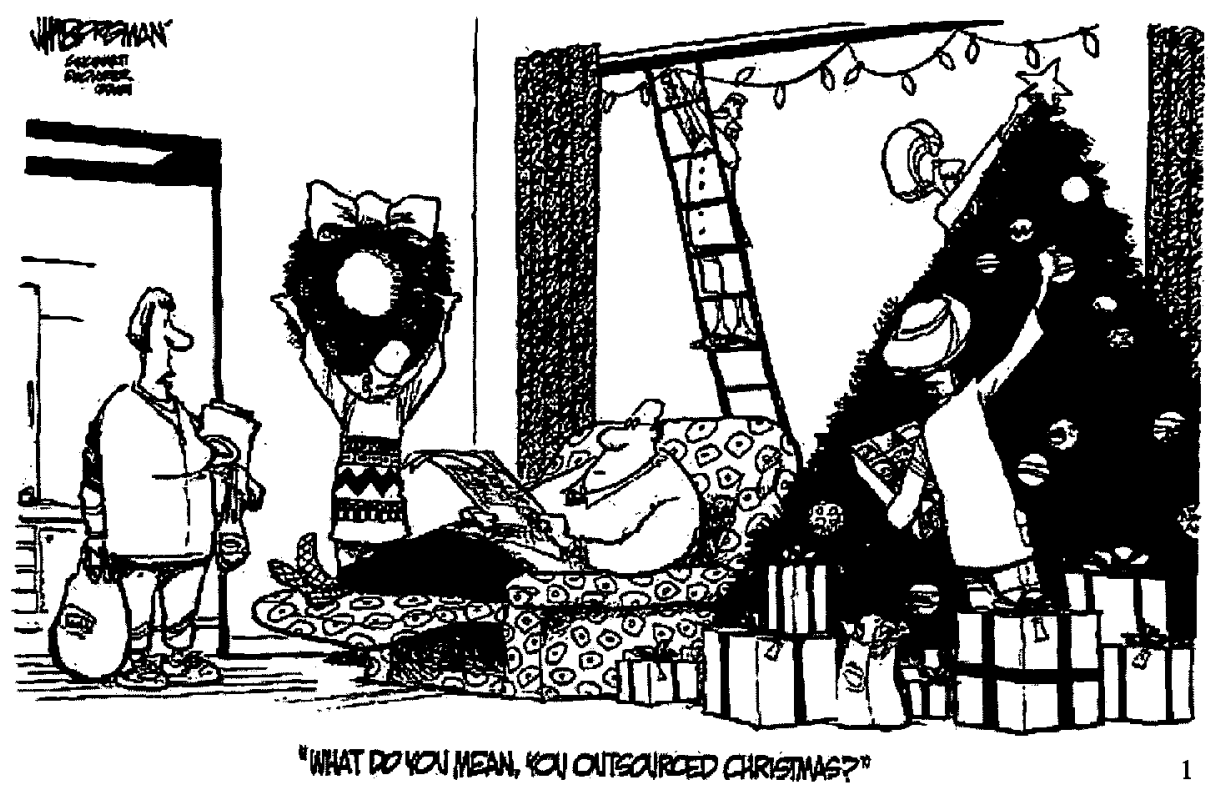

from less developed nations such as India and China are able to participate in highly sophisticated work without leaving their home countries, while previously they would have had to relocate for the same opportunities. ${ }^{2}$

This article addresses the impact of this aspect of globalization on the world of legal and law-related services. We ask whether the market for these services is "flattened" by globalization in the same ways described by Friedman. ${ }^{3}$ Our focus here is on offshore outsourcing, which is possible when services are divided into discrete tasks that are delegated to less-costly service providers located far from the outsourcer. A business outsources by segmenting off an aspect of its activities and retaining a third party to perform the activities. ${ }^{4}$ Offshor-

1. (C) King Features Syndicate (Jim Borgman, CINCINNATI ENQUIRER, Dec. 7, 2004) available at http://borgman.enquirer.com/weekly/daily_html/2004/12/120704borgman.html.

2. Thomas L. Friedman, The World Is Flat: A Brief History of the Twenty-first Century (2005).

3. For a somewhat different response to this question, see Laura Lewis Owens, With Legal Services, World Is Flat, NAT'L L.J., Jan. 15, 2007, at 15.

4. See, e.g., The Real Offshoring Question, Executtve AGENDA: IDEAS AND INSIGHTS FOR Bus. LEADERS, Vol. 7(3) 2004, at 49, 50, available at http://www.atkearney.com/shared_res/pdf/ EA73_RealOffshoring_S.pdf ("We define outsourcing as when a company assigns its activities, and sometimes its people, to a third party."). 
ing, on the other hand, occurs when a business relocates its activities to a location that allows the business to capture some efficiency, often through lower labor costs. ${ }^{5}$ The developments that drive globalization, including advances in transportation and technology, also support outsourcing offshore. Examples are ubiquitous, and include relocation of customer call centers, data processing activities, medical transcription services, ${ }^{6}$ software design activities, ${ }^{7}$ accounting services, ${ }^{8}$ and even interpretation of $\mathrm{x}$-rays. ${ }^{9}$ One estimate is that "as many as 3.3 million [white-collar jobs could be shipped abroad] by $2015 . " 10$

Law practice tends to follow business, whether we focus on interna-

5. See id. ("Our definition of offshoring is the search for a lower cost location for business processing."). Of course, there are other purposes of offshore outsourcing, as well as business purposes. See, e.g., Michael Braga, Wary of change, Sarasota Herald-Trib. (Florida), Jan. 16, 2005, at D1 (describing outsourcing in the 1990s being fueled by "U.S. software firms ... hunting for programmers to help them deal with the much-hyped Y2K computer bug."); Jane Mayer, Outsourcing Torture, NEw YORKER, Feb. 14, 2005, at 106, available at www.newyorker.com/archive/ 2005/02/14/050214fa_fact6 (discussing the U.S. government's outsourcing of interrogation and torture).

6. For a description of medical transcription, see Medical Transcription A to Z, http:// www.medtranscription.com/info.htm (last visited Feb. 13, 2005).

7. See Posting of Todd Ogasawara to O'Reilly Developer Weblogs, Jan. 4, 2004, 21:36 EST, http://www.oreillynet.com/pub/wlg/4126 (last visited Apr. 30, 2007) (referring to a survey by Software Development Magazine that reported more than 50\% of design projects being outsourced offshore).

8. See Tom Herman, Tax Report: Ethics Rule May Help Taxpayers Learn if Firms Outsource Returns, WALL ST. J., June 29, 2005, at D2; Kris Maher, Next on the Outsourcing List, WALL ST. J., Mar. 23, 2004 (listing medical, animation, insurance, digitizing, desktop publishing, telemarketing and financial jobs as being outsourced; accounting, bookkeeping and tax preparation work are included in the "financial" category of outsourced jobs). But see Braga, supra note 5 (reporting on resistance of Southwest Florida accountants to outsource preparation of tax returns to India: “'[W]e decided not to do it [outsource their Form 1040 work offshore] because we didn't feel it was what our clients would want.' ... 'It came down to a quality control issue and whether we would be ashamed to tell our clients.'").

9. See Susan J. Bliss, Should DUR Be Outsourced Offshore to Cut Costs?, Drug Topics, Dec. 13, 2004, http://www.drugtopics.com/drugtopics/article/articleDetail.jsp?id=137451 ("For at least two years, many U.S. hospitals have been beaming digital X-rays to radiologists in Australia and India for interpretation. 'Nighthawk' services (so called because they work during our nighttime hours) are staffed by U.S. licensed doctors or Indian M.D.s who communicate with U.S. physicians.").

10. Braga, supra note 5. See also Leigh Jones, The 24hour Firm: a No Sleep Zome?', Nat'L L. J., Nov. 14, 2005 (suggesting that " $[\mathrm{i}] \mathrm{n}$ 2004, an estimated 12,000 legal jobs, including those in research and document production and preparation, were sent offshore") (citing U.S. Bureau of Labor Statistics and Forrester Research). Forrester forecasts that 35,000 legal jobs will have moved offshore by 2010 . The company also estimates the value of legal services offshored to India in 2005 at approximately $\$ 61$ million, a number it forecasts reaching $\$ 605$ million by 2010 . Overseas Savings, InSIDE COUNSEL, Feb. 2007, at 57. See generally Karen Krebsbach, Inside the Outsourcing World 
tional expansion, diversity of the workforce or the acceptance of more casual standards of business attire. Outsourcing is no exception. Law firms have outsourced their libraries ${ }^{11}$ and certain support services, such as data processing and copying, ${ }^{12}$ for some time. Today, certain law firms outsource significant portions of their back-office support services. ${ }^{13}$ One foreign offshore firm offers law firms the option of outsourcing ten categories of activities, including financial and accounting services, presentation preparation services, and litigation support services. ${ }^{14}$ The outsourced work might be accomplished in a lower-cost area of the United States (which is sometimes called "homeshoring "or "farmshoring" ${ }^{15}$ ) or in another country, in either case taking advantage of lower labor and overhead costs.

Attention recently has shifted from outsourcing back-office, administrative and support functions for law firms and legal departments to outsourcing legal and law-related services themselves. ${ }^{16}$ In this shift, the

of India, BANK TECH. NEWs, Jan. 1, 2007, at 26 (reporting that outsourcing-not limited to legal outsourcing- "has created more than 1.3 million jobs" in six Indian cities during the last decade).

11. Sherrie F. Nachman, Baker $\mathcal{E}^{2}$ McKenzie to Librarians: Check Out, AM. LAw., May 1995, at 14.

12. Nathan Koppel, How Bad Is It, AM. LAw., Feb. 2002, at 74, 77. Firms also outsource storage and backup of their data centers. See Denton Outsources Data Centre, LeGAL IT, Apr. 27, 2006 (reporting Denton Wilde Sapte's agreement with Telstra Europe).

13. See Julie Creswell, Law Firms Are Starting to Adopt Outsourcing, N.Y. TimES, Oct. 27, 2006, at C3 (describing Clifford Chance's decision to "move big chunks of its administrative functions like accounting and technological support to an operation in Delhi, India ... [that] could eventually result in up to $\$ 18$ million a year in savings"); Amy Kolz, Wheeling, We Have a New Client, AM. LAW TECH., Sept. 2004, at S27. (Describing Orrick, Herrington, and Sutcliffe's outsourcing center).

14. Office Tiger, http://www.officetiger.com/whatwedo/legal_mar.htm (last visited Feb. 13, 2004).

15. Inside us. Outside: When Does it Make Sense for Law Firms to Outsource, Roundtable Discussion, LAW Practice TODAy, Apr. 2006, available at http://www.abanet.org/lpm/lpt/articles/ mgt04063.shtml (last visited Apr. 30, 2007).

16. Domestic outsourcing by U.S. and UK firms is more common, but outside the scope of this article. See U.S. Law Firms Outsourcing Non-Legal Work Use American, Not Overseas, Companies for Support, Legal Pub., Sept. 1, 2006 (reporting that more than $90 \%$ of law firms surveyed by ALM Research "outsourced one or more functions within the U.S."). U.S. domestic outsourcing firms include Axiom Legal Solutions, Inc., Outside GC LLC and CorpLaw Associates LLC. Heather Smith, Temps with a Twist, CORP. Counsel, Aug. 2004, at 28. See also Anthony Lin, Legal Outsourcing Looks to the Heartland, N.Y.L.J., June 16, 2004 (outsourcing of office staff to Fargo, N.D. for Piper Rudnick). On the practices of English Magic Circle firms to outsource to smaller English law firms, see Paul Hodkinson, Freshfields in Low-Mangin Property Outsourcing Push, LeGal WK., Jan. 4, 2004, available at http://www.legalweek.com/Articles/118972/Freshfields+in +low-margin + property + outsourcing + push.html; Press Release, Lovells, Lovells Wins Client Care Award for "MexicanWave" (July 3, 2003), available at http://www.lovells.com/PressReleaseDetailServlet?id $=198$ (describing Lovells' practice of referring routine legal services to "provincially-based solicitors"). 
uniqueness of law, compared to business and even to other professional services such as accounting, is crystallized. Outsourcing legal services raises special concerns that implicate the professional obligations of lawyers and our self-regulatory regime. The ethical and regulatory issues are complicated by the outsourced activities being sent offshore to jurisdictions where regulatory restrictions and judicial systems differ from those in the United States and consequently issues from unauthorized practice to enforceability of contracts may be relevant. ${ }^{17}$ Of course, these ethical and regulatory concerns are only part of the story, for outsourcing legal services implicates the judgment lawyers bring to their clients. In this regard, outsourcing legal services raises issues common to the outsourcing of any service involving judgment, nuance and experience.

In this article, we place offshore outsourcing of legal and law-related services in the larger context of globalization as it impacts the legal profession generally, and consider the ethical issues raised by offshore outsourcing, both as it exists today and as the practice may develop in the future. We begin in Part I with an examination of the existing offshore outsourcing activities of lawyers, law firms and corporate legal departments, in order to separate the hype surrounding outsourcing from reality. We then consider the motives for outsourcing, both for outsourcers and those receiving the assignments (frequently referred to as "vendors" or "providers"). In order to understand how the outsourcing relationship differs from typical lawyer-client and lawyerlawyer relationships, in Part II we construct an analytical frameworkbased on traditional relationships among lawyers and between lawyers and their clients-to consider the ethical issues raised by offshore outsourcing. In Part III we look to professional regulation for guidance on the ethical issues raised by offshore outsourcing in the context of a law firm outsourcing to an offshore service provider. Finally, in Part IV we consider the potential benefits and disadvantages to law firms and legal departments in outsourcing offshore.

\section{Contextualizing Offshore Outsourcing Through the Lens of GLOBALIZATION}

Offshore outsourcing is headline news for businesses, and legal

17. On the legal system of India in the context of outsourcing legal services, see Jayanth $\mathbf{K}$ Krishnan, Outsourcing and the Globalizing Legal Profession, 48 WM. \& MARY L. REV. 2189 (2007). 
services are following here as elsewhere.$^{18}$ Reports of offshore outsourcing of legal services are announced with attention-grabbing proclamations such as "Corporate America Sending More Legal Work to Bombay," 19 "A Passage to India," 20 "New Jersey Law Firms to Outsource from India," 21 and "More U.S. Legal Work Moves to India's Low-Cost Lawyers." ${ }^{22}$ Despite the warnings implicit in these banners, however, most of the reports tell of offshore outsourcing of back-office and support services for lawyers rather than of legal advisory services. ${ }^{23}$ Back-office work is substantial in terms of dollars involved: one estimate is that the "top 200 [U.S.-based] law firms spend more than $\$ 20$ billion a year for back-office work." 24

In addition to administrative back-office work, services commonly performed by paralegals and new law graduates are being outsourced, including preparation of patent applications and document review. Outsourcing of these sorts of activities illustrates how services can be disaggregated or "unbundled" for purposes of capitalizing on the efficiencies of sending work to lower cost service providers situated

18. In fact, an average of at least three news articles on offshore outsourcing of legal services has been published each month since March 2004.

19. Ellen L. Rosen, Corporate America Sending More Legal Work to Bombay, N.Y. TIMEs, Mar. 14, $2004, \S 10$, at 1 .

20. Rich Smith, A Passage to India, Motley Fool, Jan. 26, 2004, http://www.fool.com/ investing/general/2004/01/26/a-passage-to-india.aspx.

21. E.g., New Jersey Law Firms to Outsource from India, HiNDu (India), Mar. 24, 2004, available at http://www.hinduonnet.com/2004/03/25/stories/2004032503211800.htm.

22. Eric Bellman \& Nathan Koppel, More U.S. Legal Work Moves to India's Low-Cost Lawyers, WaLL ST. J., Sept. 28, 2005, at B1.

23. The comments of Kirkland \& Ellis partner, Gregg Kirchhoefer, are apropos: "[I]t could be 50 years before lawyers in India do more than 'routine, prosaic' American legal work. . . 'Firms like ours that work on complicated and significant cases don't expect the main part of that work effort to be done [offshore] at the same level we do it,' he says." Id. But see Trends, 05-02 ParTner's REPORT FOR LAW FIRM OWNERS (Feb. 2005) (predicting that by the year 2025, "[o]utsourcing and offshoring of legal work will be the norm.... Research may be done in India, transcript summaries may be done in the Philippines, and document preparation will be done in Mexico."); Associate Management, 04-11 PARTNER's RePORT FOR LAW FirM OWNERS (Nov. 2004) ("One government study suggests that $8 \%$ of the lawyer jobs in the U.S. will be outsourced over the next five years" according to Ward Bower of Altman Weil, Inc.); Jennifer Fried, U.S. Legal Jobs Being Shipped Overseas, Western MASS L. Trib., Oct. 17, 2004, at 1 ("Forrester Research, Inc., a Cambridge, Mass-based market research firm, predicts that more than 489,000 U.S. lawyer jobs, nearly $8 \%$ of the field, will shift abroad by 2015."). See discussion supra note 10 .

24. Tommy Fernandez, Low Costs Make the Case for Outsourcing Legal Work, Crains N.Y. Bus., Sept. 13, 2004, at 21. In terms of savings to the law firms sending back-office work offshore, see discussion supra note 13. 
overseas. ${ }^{25}$ Discrete tasks are outsourced to individuals, who may be licensed lawyers or experts in other fields such as engineering, working in remote locations. Once the outsourced work is completed it is integrated into the larger context of the client project, and this integration typically occurs in the United States. One of the earliest examples of offshore outsourcing by a law firm is the Bickel \& Brewer law firm of Dallas, which opened a back-office support facility in India in 1995 in which it uses lawyers and non-lawyers to "scan, code, index and abstract documents" ${ }^{26}$ to support its Texas litigation practice.

Often, outsourcing is accomplished with the aid of an intermediary outsourcing firm. ${ }^{27}$ Several intermediary firms were founded by U.S. lawyers with elite credentials, including Mindcrest (Ganesh Natarajan and George Hefferan, both formerly with McGuire Woods's Chicago office $^{28}$ ) and Atlas Legal Research (Abhay "Rocky" Dhir, former law clerk to U.S. District Judge Jerry Buchmeyer ${ }^{29}$ ). Others are organized abroad, including Manthan Services, which has " 120 Indian-trained lawyers, including two UK qualified solicitors and 50 senior lawyers" ${ }^{30}$ and IP Pro, an affiliate of a Mumbai law firm. ${ }^{31}$ Still another model is

25. See Jonathan V. Beaverstock, Managing Across Borders: Knowledge Management and Expatriation in Professional Service Legal Firms, 4 J. ECON. GEOG. 157, 157 (2004) ("Processes of economic globalization have continued to splinter the productive activities of transnational corporations ..."); Owens, supra note 3 ("Unbundling allowed lawyers to carve out particular roles, for example in litigation, without taking responsibility for the entire matter.").

26. Helen Coster, Briefed in Bangalore, AM. LAw., Nov. 2004, at 98.

27. Intermediary firms for outsourcing legal services include Mindcrest, Atlas Legal Research, Intellevate, Lawwave.com, Lexadigm Solutions, OfficeTiger and Quislex, IP Pro. Joy London, in her blog www.excitedutterances.com, has identified 29 outsourcing intermediary firms in India. See http://excitedutterancesblogspot.com/2005_08_01_excitedutterances_ archive.html\#112544823759972718 (last visited Oct. 6, 2005); Karen Asner, The Inside Scoop on Law Firm Outsourcing, Law.cOM, Nov. 15, 2006, http://www.law.com/jsp/article.jsp?id=1163498721926 (last visited Feb. 2, 2007); Coster, supra note 26. See generally Krishnan, supra note 17.

28. Geanne Rosenberg, Offshore Legal Work Continues To Make Gains, NAT'L L. J., May 17, 2004, at S3; Ameet Sachdev, Law Firms Slow to Outsource-Confidentiality Outweighs Savings, CHICAGO TRIB., Jan. 19, 2004.

29. John Council, Lauyer Sets Up Research Business, NAT'L L.J., May 17, 2004, at 51 . In addition, a 2004 joint venture was formed between OfficeTiger and law firm consultants Hildebrandt International. Law Firm Outsourcing Is Aim of New Joint Venture, posted to SBPOA, http:// www.sharedxpertise.org (June 8, 2004) (last visited July 15, 2004).

30. William O'Shea, Caseload Grows for Advocates in Absentia, Fin. Times (London), Oct. 10, 2004 , at 10.

31. Karl Schoenberger, Looking for Legal Work Companies Turn to India to Save Lauyer Expense, Augusta CHRON. (Georgia), Jan. 23, 2005, at F01; Law Firm Outsourcing Is Aim Of New Joint Venture, supra note 29 (Mindcrest also boasted that "many of [its] outsourced lawyers . . . had training from U.S. law schools ..."). 
the expansion into legal process outsourcing from business process outsourcing followed by OfficeTiger, now owned by R.R. Donnelly. ${ }^{32}$ These outsourcing intermediaries identify foreign lawyers to work on outsourced projects, communicate assignments to them, set and collect fees, and might even provide U.S.-lawyer review of outsourced work. ${ }^{33}$ Each of the outsourcing firms is careful to note that they are not providing "legal services" and are not involved in any lawyer-client relationship.

Such disclaimers raise important issues about the nature of the services being outsourced, which in turn leads to the dilemma of separating legal from law-related and non-legal services. When legal services are outsourced, the same rules of professional conduct regulating lawyers' activities generally apply, triggering concerns about unauthorized practice and other ethical issues. Law-related services, in contrast, raise a relatively limited set of ethical issues. Finally, back office, support, and paralegal services are appropriately performed by non-lawyers and generate application of the ethical rules in the larger context in which the services are integrated. The distinction among legal, law-related and non-legal services implicates the boundaries of the practice of law, which leads us to the circuitous definition that "the 'practice of law' is the rendering of professional services to a person who believes that he or she is a client dealing with a lawyer." ${ }^{34}$ Unfortunately, this raises at least as many questions as it might resolve, since there is no general agreement on the definition of "the practice of law" and the activities currently being outsourced skate close to the

32. See Assif Shameen, The Philippines'Awesome Outsourcing Opportunity, Bus. WK. ONLINE, Sept. 20, 2006, http://www.businessweek.com/print/globalbiz/content/sep2006/gb20060919_ 639997.htm.

33. As one author notes:

There are a few different emerging models. Vendors like Lexadigm Solutions and Lawwave.com rely exclusively on Indian lawyers to conduct low-level legal work and analysis. Others, like OfficeTiger, use a mix of lawyers and trained professionals to handle legal and non-legal tasks such as managing conflicts databases and document management and review. A few vendors specialize. Intellevate has hired an Indian staff of lawyers and Ph.D.s to conduct patent research and other IP work. The company has a dedicated team devoted just to Microsoft's patent work.

Coster, supra note 26.

34. See, e.g., Robert R. Keatinge, Multidimensional Practice in a World of Invincible Ignorance: MDP, MJP, and Ancillary Business after Enron, 44 ARIz. L. REv. 717, 723 (2002) ("A starting point is to recognize that the most workable definition of the "practice of law" is the rendering of professional services to a person who believes that he or she is a client dealing with a lawyer."). 
divide between "legal" and "support" services. Examples of the type of work outsourced offshore include "patent applications and litigation support,"35 "legal research and pieces of M \& A transaction[s],"36 and even drafting pretrial motions and briefs. ${ }^{37}$ Each of these activities might be performed by lawyers, paralegals, or other support staff working under the supervision of lawyers.

More insight into outsourcing might be gained by focusing on the substantive areas of law involved. For example, much of the outsourced work sent offshore relates to patent law. This may be revealing in itself of the limits of outsourcing, since patent law is highly technical and involves engineering expertise, as well. One description of patent application work divided a hypothetical application project into six separate tasks preliminary to compiling and integrating the application. Each of these tasks might be outsourced and several of them involve activities that easily could fall outside the definition of legal services, including searching for prior art, drafting specifications, and preparing drawings. ${ }^{38}$ Certain Indian-based outsourcing firms focus specifically on services related to "patent research, analysis, drafting and patent record management." 39

While patent law may lend itself to outsourcing offshore because of the separability of the work and its reliance on the expertise of

35. Ward Bower, Law Firm Marketing: Intellectual Property Practice Strategies, N.Y.L.J., Dec. 20, 2004, at 4.

36. Coster, supra note 26 (citing Stites \& Harbison, a 250-lawyer Louisville-based law firm).

37. E.g., Renee Deger, More Companies Now Follow DuPont's Legal Model, NaT'L L.J., May 17, 2004, at S6. See also Rosenberg, supra note 28 (noting that Hildebrandt International, a law firm consulting firm, reported that the "categories of legal work that have been performed offshore by non-U.S. lawyers include legal research; assistance in the drafting of legal memos and briefs; discovery work; assembling facts in support of litigation claims; and patent, trademark and ERISA work.").

38. See Alok Aggarwal, Offshoring Patent Drafting and Prosecution Services, INTELL. Prop. TodaY, May 2005, at 38-39. Aggarwal states:

A patent application typically consists of the following activities: (a) prior art searching, (b) drafting background, (c) drafting specifications, (d) drafting claims, (e) drafting summary, (f) preparing drawings, and ( $g$ ) a final review, modifications and filing. Although the last activity has to be always performed by a USPTO registered attorney or agent, who usually also becomes the attorney of record, other activities can be either done by the IP professionals in a remote location or by the IP professional located in the US.

Id. See also Braga, supra note 5; Schoenberger, supra note 31.

39. O'Shea, supra note 30. 
nonlawyers, it is not typically the area of substantive law that determines susceptibility to outsourcing offshore. Rather, the focus is on identifying work that is routine or "fungible." ${ }^{40}$ General research projects such as a search for the law in each U.S. jurisdiction related to a particular insurance matter have been the subject of offshore outsourcing arrangements. ${ }^{41}$ But, in addition, the outsourcing firm, Lexadigm, reported that its work included preparation of briefs for submission to the U.S. Supreme Court and several Circuit Courts of Appeals. ${ }^{42}$ Even aspects of mergers and acquisitions have been outsourced offshore. ${ }^{43}$

Offshore outsourcing typically is sold as a means to save money. The fees for lawyers in India-the most typical site of offshore outsourcing of legal services to date ${ }^{44}$ - are extraordinarily low compared to U.S. law firm rates. ${ }^{45}$ For example, rates charged by the outsourcing intermediary, Lexadigm, for legal research range from $\$ 60$ to $\$ 80$ per hour depending upon the turnaround time required. Lexadigm advertises

40. Owens, supra note 3 ("David Galbinski of Lumen Legal ... talk[s] to in-house counsel about dividing work into fungible and nonfungible categories, including in the fungible category such tasks as review of electronic documents, contract review, patent application drafting, and even legal research and writing."). But see Jeremy Quittner, Beyond IT: Outsourcers Expand Services, AM. BANKER, Nov. 9, 2006 (reporting that "the focus of outsourcing is changing" and includes, for example, the development of management consulting expertise by outsourcing intermediary firms).

41. Coster, supra note 26 , quoting sole practitioner Solan Schwab:

\begin{abstract}
"When I go home at 6, I can have them do the grunt work, research, and proofreading that I would otherwise have other people do," says Solan Schwab, a New York-based solo practitioner who outsources research projects like analyzing state-by-state insurance regulations with QuisLex, which has 12 lawyers in Hyderabad. "Then, when I come in in the morning, I receive a beautiful e-mail with research done exactly how 1 like it."
\end{abstract}

Id. See also Jyoti Kamal \& Rahul Kumar, U.S. Legal Claims Processing to be Increasingly Offshored to India, ECON. TIMEs, Dec. 12, 2004 (describing Stites \& Harbison's use of offshore outsourcing for legal research).

42. NPR On-Air Interview with Puneet Mohey, President of Lexadigm (May 1, 2005), available at http://www.npr.org/templates/story/story.php?storyId $=4626716$ (last visited Apr. 30, 2007). This is further discussed in Krishnan, supra note 17.

43. Kamal \& Kumar, supra note 41.

44. But see Bring the Gavel Dowm, Bus. \&c Fin., July 27, 2006 (describing Irish law firms as potential competitors of India for the outsourcing of legal services from the U.S.); Michele Chabin, New Life, On the Night Shift, N.Y. JEWISH WK., July 14, 2006 (discussing legal services outsourcing being done in Israel).

45. But see Beginning of the End?, INDIA Bus. INSIGHT, Aug. 31, 2006 (reporting on the decreasing growth rate of the business process outsourcing business in India, including legal services, as a result of higher wages being demanded and problems hiring and retaining high quality personnel). 
these services as being performed by its research specialists who are Indian law school graduates with several years of work experience. ${ }^{46}$ Another source puts the hourly rate for Indian lawyers as low as $\$ 2$ per hour. ${ }^{47}$ The cost differential obviously is significant for lawyers working in a variety of organizations, from the largest corporations to sole practitioners; however, reports of substantial cost savings from outsourcing offshore also may inflate the cost of outsourcable services by referring to rates charged by relatively senior U.S. lawyers whose services are not of the type being outsourced. ${ }^{48}$

Aside from cost savings, offshore outsourcing also captures time efficiencies related to the time change between the outsourcer's location and the site of the recipient of the outsourcing assignment. DuPont initially decided to outsource patent application work to Indian scientists in order to save money, "but soon found there were additional benefits from the 10-hour time difference, such as being able to send assignments as you leave for the day and having the work completed when you arrive[] the next morning." 49 The same time difference, however, also has been cited as a negative factor against outsourcing because it serves as a barrier to the communication between the outsourcer and receiving attorneys and the effective supervision over the work outsourced. ${ }^{50}$ Beyond the timing efficiencies, for smaller firms and sole practitioners outsourcing allows them to accommodate the "erratic work-flow that doesn't justify the overhead of a full-time [U.S.-licensed] staff." ${ }^{51}$ In addition, it might be used to enable a small firm to represent a client on a project that demands more, in terms of personnel, than the firm typically could provide. ${ }^{52}$

46. See Outsource Legal Research India, http://www.lexadigm.com/about-lexadigm.php (last visited Apr. 20, 2007). Lexadigm attorneys earn between $\$ 6,000$ and $\$ 36,000$ annually, according to Daniel Brook, Made in India, LEGAL. AFF., May/June 2005, available at www.legalaffairs. org.

47. Laxmi Devi, Indian Legal Eagles Wing Their Way to BPOs, ECON. TIMES, June 9, 2005.

48. See, e.g., Legal Outsourcing Firm Gets Funding, Hindu (India), Aug. 5, 2006 (referring to work billed at up to $\$ 600$ per hour as being outsourced).

49. Jeff Blumenthal, A Gateway to India?, LEGAL INTELLIGENCER, May 18, 2005.

50. Id. ("When I assign work to an associate or a paralegal, they come into my office and we go through several iterations when we are dealing with a patent application," [Gregory] Lavorgna [chairman of IP firm Drinker Biddle \& Reath] said. "And that's just harder to do when they are so far away. We have looked into it and I know it is a way to control costs. I just don't think it will wind up saving firms as much as advertised when you factor everything into the equation.").

51. Coster, supra note 26.

52. Taylor H. Wilson, Outsourced Around the World in a Billable Hour, IN-House TeXAs, May 1, 2006. 
Despite these benefits, top U.S. law firms generally focus on providing sophisticated services and are unlikely to embrace offshore outsourcing as a new organizational model. These firms, which certainly include those on the American Lawyer list of the 200 highest-grossing United States law firms, ${ }^{53}$ focus on cutting-edge and high fees work at the opposite end of the spectrum from the routine and low-level work currently being outsourced offshore. ${ }^{54}$ They sell judgment and experience more than legal research. It is anathema to the identities of these firms, as providers of highly sophisticated expertise, to connect with service providers at the other end of the spectrum whose attraction is their low cost. Moreover, the more routine aspects of the work of these firms is critical to their ability to train new lawyers, since it allows them to offer sufficient routine and lower stakes experiences to enable new law school graduates to develop the kind of judgment that forms the basis for the reputation of the firms' top lawyers.

Reputation for quality is among the most important assets of any law firm, whether or not its work actually includes more routine services. An offshore outsourcing relationship may be perceived as undermining that reputation because of the suspicion that the foreign legal education and training of the lawyers providing the outsourcing services is different and consequently of lower quality. ${ }^{55}$ In addition, there is a built-in assumption in the market for sophisticated legal advice that the client gets what it pays for, so a higher billing rate indicates higher quality of the advice and advisor. Outsourcing admits commodifica-

53. See The Am. Law 200, AM. LAw., June 2007.

54. This is not to say that sophisticated work might not be outsourced offshore in the future. But see comment of Gregg Kirchhoefer, in Bellman \& Koppel, supra note 22; comment of Bruce MacEwen, Adam Smith, Esq., Aug. 30, 2005, http://www.bmacewen.com/blog/archives/ globalization (last visited Oct. 6, 2005):

\footnotetext{
While the future projections come from consultants with, the cynical might say, an interest in generating excitement about the numbers, they forecast 35,000 'U.S. law jobs' moving to India by 2010 and just over twice that number by 2015. Does 'U.S. law jobs' strike you as a fuzz-phrase? (A: Yes.) Are these Bates-stamping clerks and digital-scanning jockeys, or AmLaw 100 partner equivalents? My guess is that for the duration of the careers of most of you reading this, it will not be the latter.
}

Id.

55. Of course, certain outsourcing providers may be U.S.-trained lawyers. This is not the common model, however. See, e.g., Interview with Puneet Mohey, supra note 42 (reporting that none of Lexadigm's employees are U.S.-trained lawyers). Nonetheless, a number of the outsourcing intermediary firms were created by U.S.-educated and licensed, experienced lawyers, whose participation in the venture provides legitimacy and trustworthiness. 
tion-an admission few firms will concede even if there is no rational basis for claiming participation in the high-fees-sophisticated tier of the market. Perhaps few clients, too, would be satisfied with the moniker "routine" attached to the legal issues that cause them to retain outside counsel.

Finally, to the extent we limit our discussion to offshore outsourcing that utilizes non-U.S. law graduates, the distance between U.S.-based firms and outsourcing deepens. U.S. lawyers have been reluctant to include foreign-trained lawyers in their domestic organizations, even as foreign lawyers have become an increasing presence in United States law schools. Law firms point to state regulations that limit the ability of foreign lawyers to sit for the bar examination as one justification for their exclusion. But the reluctance to embrace foreign-educated lawyers is limited in large part to the location of their offices. U.S. firms rely increasingly on foreign lawyers to staff their foreign offices. ${ }^{56}$ Regulation plays a part, but economics does, too-hiring local lawyers is less expensive in terms of compensation (including cost of living and hardship allowances, for example), stability and retention, which can be costly for law firms. But as to their domestic offices and practices, United States firms' reluctance to hire foreign-trained lawyers likely relates to three factors: first, the assumption that most foreign lawyers will return to their home jurisdictions after a relatively brief period in the United States; second, a concern that training foreign lawyers may require more time than training their U.S.-educated counterparts; and third, the nature of the work assigned to new law graduates, which is intensely language-focused and consequently presents a considerable challenge to lawyers whose first language is not English. Given the reluctance of U.S. law firms to hire foreign lawyers and train them in their domestic offices where opportunities for monitoring are substantial, it is unlikely that these firms would feel comfortable sending work offshore to be performed by similarly educated individuals in circumstances that make monitoring and training difficult.

While law firms may dabble in offshore outsourcing, corporate legal departments reportedly have been more serious about taking advantage of the cost savings available by sending some of their work offshore. The general pressure on corporate officers to lower costs also applies to legal costs. In addition, corporate general counsel (GCs) may

56. Most of these foreign-educated lawyers working in foreign offices of the top 60 U.S. law firms have not earned LLMs or other law degrees in United States law schools. See Carole Silver, Winners and Losers in the Globalization of Legal Services, 45 VA. J. INT'L L. 897 (2005). 
be more likely to try offshore outsourcing than law firms because they are influenced by the successful experiences of other corporate departments that have outsourced work overseas. ${ }^{57}$ According to Ganesh Natarajan, a founder of Mindcrest, a legal outsourcing firm based in Chicago, "Corporate law departments ... are much more apt [than law firms] to make use of outsourced legal staff, often because other corporate divisions also have cut costs through outsourcing." 58

In analyzing offshore outsourcing in the corporate counsel context, we are mindful that the line distinguishing lawyers from non-lawyers in terms of function is blurred. Corporations use lawyers in a variety of capacities that do not require a license. ${ }^{59}$ Corporate compliance officers are an example of corporate positions that may be staffed with lawyers, and when they are, may assume a more "law minded" role that influences the relationship with the corporation's general counsel. As one article on legal outsourcing recently noted, "[w] hat constitutes lawyering can get fuzzy."

Moreover, corporations already outsource their legal work to outside counsel on a regular basis. When they turn to non-U.S. lawyers in an offshore outsourcing relationship, GCs may need to assume more responsibility for monitoring those performing the work. Nevertheless, the nature of the relationship between the GC and the lawyers performing the outsourced work will not be substantially different, regardless of whether the outsourcing lawyer is licensed in the same jurisdiction as the GC and works in a law firm down the street from the corporation's office or is licensed in a foreign jurisdiction and occupies an office thousands of miles away.

General Electric and DuPont have led the charge on offshore outsourcing of legal services. General Electric reportedly hired and

57. See Overseas Savings, supra note 10 ("What is exciting for GCs is that they now can act like the rest of the corporation and think about executing business processes on a global basis,' says Raymond Bayley, CEO of Novus Law, a firm that outsources routine work to lawyers in India."). According to Leon Steinberg, CEO of Intellevate, an Indian outsourcing firm, "'The Fortune 500s are already doing work overseas. If they have research facilities in India, they know they can put their legal over there as well." See also O'Shea, supra note 30.

58. Law Firm Outsourcing Is Aim of New Joint Venture, supra note 29.

59. For example, compliance officers may or may not be lawyers. See generally Ben W. Heineman, Jr., Imagination at Work, AM. LAw., Apr. 2006, at 73 (describing the importance of lawyers as "members of the business team" and reporting on several GE general counsel who moved into business roles).

60. Nathan Koppel, Nation Builder, CoRP. COUNS., Jan. 2005, at 100 (describing the role of a Reed Smith partner, Sanjoy Bose, who also serves as president of project finance consulting firm, GFS Group). 
trained Indian lawyers to create its own in-house Indian legal staff. ${ }^{61}$ According to one report, "By creating its own in-house legal department in India, GE reports that in 2001 its plastics division saved approximately half a million dollars that would otherwise have been spent on American advice purchased from American law firms. By 2002, those savings had already increased by $40 \% .{ }^{\prime 62}$ The DuPont Legal Model advocates using alternatives to outside law firms, including outsourcing to U.S.-licensed temporary attorneys and offshore outsourcing. ${ }^{63}$ Other corporations that reportedly have outsourced certain legal work offshore include BorgWarner, ${ }^{64}$ Cisco Systems, ${ }^{65}$ Microsoft, ${ }^{66}$ and Andrew Corp. ${ }^{67}$ These companies have outsourced research relating to patent applications and IP prosecution, among other matters; suggestions for outsourcing offshore also include reviewing documents for discovery, preparing "first drafts of responses to interrogatories, or [doing] privilege reviews...." W8 West Publishing even uses Indian lawyers to prepare their case summaries, which form the basis for legal research searches by U.S. practitioners. ${ }^{69}$

Nevertheless, even among GCs offshore outsourcing is not uniformly embraced; indeed, according to a 2004 survey of 167 Chief Legal Officers conducted by the Association of Corporate Counsel and Altman Weil, Inc., fewer than $2 \%$ of the corporations surveyed use offshore outsourcing for any of their legal or back office work, while $8 \%$ predicted they would consider offshore outsourcing for legal

61. See Coster, supra note 26 ("In 2001, General Electric Company established a legal team in Gurgaon, India, with lawyers and paralegals who draft documents like contracts."). This is also referred to as a "captive" offshoring arrangement. See The Emerging Indian Legal Offshoring Opportunity, INVESTREND, Apr. 18, 2006 (describing captive centers for Oracle and Cisco as well as $\mathrm{GE)}$.

62. Smith, supra note 20.

63. Deger, supra note 37; see also Pete Engardio \& Assif Shameen, Let's Offshore the Lawyers, Bus. WK. Sept. 18, 2006, at 42 (reporting on DuPont's use of Filipino lawyers, "including three who have passed U.S. bar exams").

64. Rosen, supra note 19.

65. Geanne Rosenberg, On the Web; Use of Offshore Legal Work Makes Gains with Help of Internet, Telecommunications and Emest Hemingway, BRoward Dally Bus. ReV., Apr. 2, 2004, at 9.

66. Schoenberger, supra note 31.

67. The Andrew Group is "an Orland Park, Ill., manufacturer of telecom infra-structure equipment, [that] has cut back on its use of American outside counsel by sending more of its patent application work to Baldwin Shelston Waters, a law firm in Wellington, New Zealand." Fried, supra note 23.

68. Rees Morrison, Litigation Fee Liposuction, CorP. Couns., Oct. 2003, at 71.

69. Smith, supra note 20. 
and/or back office work in the foreseeable future. ${ }^{70}$ Only $1.2 \%$ of the 149 respondents to a survey by the Corporate Legal Times, the source for their $8^{\text {th }}$ Annual Report of Corporate Law Departments, indicated that they had outsourced work to foreign firms as a way to control costs, compared to $8.4 \%$ who indicated that they had outsourced work to U.S. law firms. ${ }^{71}$

The reluctance to invest more in offshore outsourcing may be related to concerns about the need for supervision and monitoring. Generally, GCs purchase expertise in their use of outside counsel, supplementing their own substantive knowledge and familiarity with their company's operations with the expertise of lawyers working in firms, whose experience in representing multiple clients gives them insight into a larger and different context of legal issues than that available to an in-house lawyer. It is the judgment and experience of the outside counsel that makes them valuable, although technical and more routine tasks also likely are performed. In offshore outsourcing, GCs essentially are going in the opposite direction: rather than buying expertise they are buying services for which they must serve as a reviewer and expert supervisor. Such supervision reduces the cost savings attainable through outsourcing. Of course, the GCs might contract with their outside firm to perform the reviewing and monitoring function, but in either case, review costs money. In expressing concerns about the quality of offshore outsourcing services, GCs may in fact be concerned about the efficiency of outsourcing in light of this need for supervision. That which is outsourced returns as increased demand for high-level supervision within the GC's organization. ${ }^{72}$

Nevertheless, outsourcing offshore allows GCs to challenge the traditional role of the corporate law firm. Sending routine matters

70. Survey results are available at http://www.acca.com/Surveys/CLO2004.pdf and http:// www.altmanweil.com/pdf/CLO2004.pdf (last visited Feb. 18, 2005). But see Rob Preston, Outsourcing Customers Send Some Mixed Signals, INFO. WK., Feb. 19, 2007 (reporting on a KPMG survey on global outsourcing (not limited to legal services) and finding " $89 \%$ of the customer organizations surveyed say they plan to maintain or increase their current level of outsourcing."). See generally $A l l$ Abroad, MONEY MGMT., Dec. 1, 2006 (reporting on the savings and costs associated with business outsourcing and the need to take a holistic approach to offshoring in order to produce long-term financial gains); Uyen Vu, Manitoba Health Authority Tums its Back on Outsourcing, CaNadian HR REPORTER, Sept. 11, 2006, at 32 (discussing the need to consider outsourcing as part of the larger business operation organization as opposed to a piecemeal approach).

71. 8th Annual Report of Comporate Law Departments, CoRP. LeGAL Timfs, May 2005.

72. Blumenthal, supra note 49 (quoting Mike Walker, DuPont's chief IP counsel, referring to outsourced patent application work performed by Indian scientists: "we found that it takes some extra effort on our part to make sure the quality is where we want it"). 
offshore through outsourcing arrangements removes the work that law firms often use to train new lawyers. Moreover, engaging outside law firms to monitor and supervise the outsourcing work of foreign lawyers causes firms to interact with foreign lawyers performing the outsourced work, and without this incentive from the client, the law firms and outsourcing lawyers may be unlikely to interact. By enabling offshore outsourcing, globalization thus brings new power to GCs, who can instruct outside firms to develop relationships with the foreign lawyers they select. GCs in this way have more leverage over the internal structure of their outside law firms and may demand international staffing in the same way that they demand diversity. ${ }^{73}$

Finally, we must consider the impact of outsourcing on those who perform the outsourced assignments. It is these workers who have most to gain from the flattening effect described by Friedman, to the extent outsourcing offshore yields such gains. For foreign lawyers who receive the outsourcing assignments, working as an outsourcing lawyer offers the opportunity to take advantage of globalization's ability to destabilize the local legal market. ${ }^{74}$ In India, for example, success in the legal profession is closely related to social status. "The combination of caste with social networks produces a highly stratified profession." 75 At the same time, regulation keeps the Indian legal market essentially closed to foreign lawyers and law firms. But globalization, through outsourcing, allows the local and foreign lawyers to meet and bypass the rigidity characteristic of the old professional hierarchies. Indian lawyers can gain status offered by globalization without leaving home by linking

73. See Jonathan D. Glater, Clients Push Law Firms to Outsource Research, Int'l Herald Trib., Jan. 14, 2006, at 14 (quoting John Sacripanti of McDermott Will \& Emery, describing as "a lost opportunity" a client's decision to outsource legal research to a domestic legal outsourcing firm). On diversity, see Heather Smith, Hue and Cry: Firms Have Begun to Respond to Wal-Mart's Urgent Call for Diversity Action, AM. LAw., Sept. 2005, at 18.

74. See Krishnan, supra note 17, for an excellent review of the current conditions in the Indian legal market. See generally Marc Galanter, Savitri Goonesekere \& William Twining, REPORT OF THE EXPERT PANEL ON THE NATIONAL LAW SCHOOL OF INDIA UNIVERstT (1996), a aailable at http://www.marcgalanter.net/Documents/papers/scannedpdf/reportoftheexpertpanel.pdf (last visited Aug. 5 2006).

75. J.S. Ghandi, Past and Present: A Sociological Portrait of the Indian Legal Profession, in LAWYERS IN SociETY 369, 376 (Richard L. Abel \& Philip S.C. Lewis eds., 1988). See also Missing Out on a $\$ 20$ Bn a Year Opportunity, Fin. ExPRESs, Oct. 24, 2006 ("The [legal] profession [in India] - be it at the Bar, the Bench or law firms-is mostly in the hands of a few families."); A Case in Point, Bus. Line, Aug. 14, 2006 (detailing opportunities for India's law professionals as: "working in a family-run law firm, often doing lowend work with little or no client contact and an insignificant pay packet; work for corporates in their legal department, which is not an option easily available to fresh graduates; work as professors, again, something almost impossible for fresh graduates with no experience."). 
with foreigners through an outsourcing relationship, even though the local profession remains closed to foreign lawyers and firms. ${ }^{76}$ Being associated through outsourcing relationships with foreign clients and law firms, as well as with U.S. law itself, brings prestige to the local outsourcing lawyers. This reputational gain from association with foreign clients and law firms is the likely explanation for the recent affiliation of Fox Mandal Little, described as "one of India's leading and oldest law firms," with a UK outsourcing firm in a joint venture to provide legal services through outsourcing arrangements. The presence of regulatory barriers to direct affiliation between an Indian and foreign law firm supports characterizing relationships in terms of outsourcing. ${ }^{77}$

Money, of course, is also an important factor. Outsourcing of legal services is generating its own substantial business; legal process outsourcing joins firms specializing in knowledge process outsourcing (which includes professionals in other disciplines, such as accounting and engineers) and business processing outsourcing (which is the broader category and is described as addressing lower-level work).$^{78}$ One source puts the value of legal process outsourcing at $\$ 250$ billion. $^{79}$ The financial impact also is significant at an individual level; the salaries for outsourcing work exceed local pay scales, although it is difficult to ascertain the amount passed on to workers. ${ }^{80}$

76. According to one lawyer working at Pangea3, a legal outsourcing firm with offices in India, working conditions also are better at outsourcing firms compared to a "standard Indian law firm." Bellman \& Koppel, supra note 22.

77. For a recent report on the willingness of the All India Bar Association to drop its opposition to allowing foreign law firms to enter the Indian legal market, see Rashmee Roshan Lall, Bar Panel Okay with Foreign Law Firms, Times of INDIA, Mar. 9. 2007, available at http:// timesofindia.indiatimes.com/World/Rest_of_World/Bar_panel_okay_with_foreign_law_firms/ articleshow/1738524.cms (last visited Mar. 15, 2007).

78. Leveraging the Knowledge Advantage, Fin. EXPREss, Dec. 22, 2006.

79. V. Hemamalini, Cobra First LPO MNC to Enter Chennai, ECON. Times (India), Jan. 6, 2007. See also IT's Davids Vying for Global Space, Hindustan TIMEs, Feb. 8, 2007 ("The legal services in the US and Europe are $\$ 300$-billion opportunity and short of anything requiring physical presence in the court or signing, every bit of this business can be outsourced,' says Pangea3 Co-CEO Sanjay Kamlani.").

80. Hemamalini, supra note 79. See Joe Leahy, Investing in India, FIN. Times AsIA, Nov. 1, 2006, at 8 ("Nasscom [the Indian outsourcing industry association] estimates that starting salaries for Indian lawyers are 20 per cent to 30 per cent of those of their US counterparts."); Legal Outsourcing Firm Gets Funding, supra note 48 ("While an U.S. lawyer was paid $\$ 400-\$ 600$ an hour, the same work was done in India in a more cost effective and efficient manner for just $\$ 50-\$ 70$ an hour," according to Pangea3 co-CEO, Sanjay Kamlani). One report described a Chandigarh lawyer earning more than $\$ 100,000$ annually through outsourcing. Lawyers Told to Face Challenges, HINDU 
Finally, outsourcing may enable local lawyers to gain important skills and training. According to one source, the quality of legal education is uneven in India's law schools, and local lawyers may receive training from the outsourcing firms that could compensate for this. ${ }^{81}$ Offering training courses also will support outsourcing firms' efforts to instill confidence in their services, and may become a tool of competition for workers. $^{82}$

The benefits of outsourcing do not eliminate the consequences of location and training differences, however. When foreign lawyers work on outsourced projects they are segregated from clients and colleagues. The separation from colleagues means that they will not receive the same training and supervision and mentoring as a young lawyer regularly working for the same firm sending the outsourced work. The work being outsourced does not require the nuanced judgment that is so valued in the legal services market, nor does it permit the outsourcing lawyer to gradually build up her expertise and experience to gain the insights that are a foundation for such judgment. In fact, by restricting the outsourcing lawyer's interaction with clients and colleagues, there is essentially no opportunity for advancement. Outsourcing thus provides opportunities at a level well below even the most junior lawyer practicing in the U.S. This is far from the flattening effect promised by globalization optimists.

Outsourcing, then, offers a complex interplay of benefits and risks. There are financial rewards available to both local lawyers and those entities initiating the outsourcing relationship, but also risks of increased monitoring and potential injury to reputation. Offshore outsourcing arrangements open spaces for lawyers to obtain additional opportunities that otherwise might well be closed to them because of local hierarchies. For GCs initiating the outsourcing referral, offshore

(India), Dec. 24, 2006 (comment of Justice G.S. Singhvi, Chief Justice of the Andhra Pradesh High Court).

81. See Ghandi, supra note 75; Legal Services Offshoring: Hype Vs. Reality, INVESTREND, Jan. 3, 2007 ("Although India produces about 79,000 lawyers from over 400 colleges every year, it is estimated that not more than $15 \%$ are capable of ensuring high-quality delivery that is demanded in this [legal process outsourcing] sector."). On the training provided by outsourcing firms, see the description on the web site of Mindcrest, one of the legal outsourcing firms using Indian trained lawyers, available at http://www.mindcrest.com/careers.htm (last visited Apr. 29, 2006) ("Our most important asset is our human capital. We recruit the best and provide them with the resources to develop as professionals. Through rigorous training and systematic performance reviews, we encourage continuous improvement in everything we do.").

82. See Krebsbach, supra note 10 (reporting that Infosys, one of the largest outsourcing firms world-wide, spends " $\$ 125$ million a year on training new recruits."). 
outsourcing offers both potential cost savings and the opportunity to influence the role and composition of outside law firms. Openly embracing offshore outsourcing, however, may negatively impact U.S. law firms' reputations and ability to market themselves as high-end advisers. For certain law firms, this risk is likely to tip the balance away from offshore outsourcing because of the threat to firms' core identities and roles. Finally, while outsourcing brings financial benefits and possible reputational gains to foreign lawyers, it does not provide them with opportunities analogous to those available in the U.S. or in firms sending the work offshore.

\section{A Relational Framework for Offshore Outsourcing}

Offshore outsourcing of non-legal work may raise political issues but it does not trigger ethical concerns. Rather, it is in the offshore outsourcing of legal services that ethical issues are implicated. The nature of outsourcing - the disaggregation of services into separate component parts, distributed to various service providers-also complicates the determination of the ethical issues involved. This division of services into discrete segments focuses attention on the service providers involved in aspects of legal services that traditionally would be subsumed in the finished product. While a project in total may clearly involve legal services and the expertise of a lawyer, the component parts may be characterized as non-legal once divided from their context. Part of the task in assessing the ethical issues involved in offshore outsourcing, then, is to determine what sort of services we are concerned about when discussing the ethical implications of offshore outsourcing.

Instead of trying to determine whether a particular activity involves the practice of law, however, we focus here on understanding the relationships created by offshore outsourcing and examine how they differ from more traditional relationships of lawyers and clients. The following Case Studies \#\#1-7, infra, clarify the continuum from typical lawyer-client and lawyer-lawyer relationships to those accomplished through an outsourcing arrangement.

In Case Study \#1, the client hires lawyer L-1 to work on a particular problem or project, and L-1 delegates certain tasks associated with the project to others within her firm. She might assign certain functions to specialists who will use their substantive expertise to resolve specific issues, such as tax or environmental concerns, and other functions to younger lawyers with lower hourly billing rates in order to help 
conserve the client's resources. ${ }^{83}$ In each instance, L-1 segments certain tasks and sends them to others in her organization.

Outsourcing takes this delegation one step further by sending the tasks to a lawyer (or law firm, as in Case Study \#5) who works outside of L-1's organization. By outsourcing, L-1 loses at least some-and perhaps complete-control over the work she delegates. While L-1 can direct her in-firm associates to work on the project in a particular manner, when she outsources the work she abdicates control over the direction and monitoring of the way in which the work will be accomplished by the lawyer who receives the outsourcing assignment, whom we will call L-O. Outsourcing involves not only a loss of control over the manner of work but also over the physical aspects of the work, which raises questions such as where the work will be performed, access to the work site, and risks posed by the work site to maintaining the confidentiality of the client's information. ${ }^{84}$ Moreover, by outsourcing the work, L-1 introduces uncertainty into her relationship with her client, since L-O may desire direct contact with the client while L-1 may wish to prevent disclosure to the client of the fact that she is outsourcing part of the job at all. When the outsourcing is sent to a non-U.S. lawyer working outside of the U.S., as in Case Study \#7, the issues are magnified-more distance yields less control.

We can imagine a continuum of lawyer-client and lawyer-lawyer relationships in which offshore outsourcing to a non-U.S. lawyer is at one extreme, and delegation to a lawyer in the same law firm office occupies the opposite end of the spectrum. In between are intermediate steps of delegation:

- Case Study \#2: L-1 refers the matter to lawyers in a domestic branch office of the same law firm;

- Case Study \#3: L-1 refers the matter to lawyers working for her law firm in its non-U.S. office;

- Case Study \#4: L-1 hires a temporary lawyer to work on the project under her supervision and in space provided by her firm;

- Case Study \#5: L-1 refers the matter to a lawyer/law firm occupying

83. Skadden Arps reportedly utilizes a system to channel work to the most efficient worldwide location. Jones, supra note 10.

84. Confidentiality is a serious problem, as evidenced by "the University of California at San Francisco Medical Center's recent scare over patient medical records. A woman in Pakistan hired to transcribe patient records threatened to reveal patient information if she was not paid money a subcontractor owed her." Deger, supra note 37. 
offices in the same city as she works, but unaffiliated with her firm; ${ }^{85}$

- Case Study \#6: L-1 refers the matter to an outsourcing firm that hires non-U.S. lawyers in a foreign jurisdiction to perform the work;

- Case Study \#7: L-1 refers the matter to a non-U.S. lawyer/law firm situated in a foreign jurisdiction and who is unaffiliated with her firm.

Each of these delegation relationships can be analyzed according to the sorts of controls that L-1 retains: control through physical proximity, control through an employment or partnership relationship, and control through the ability to effectively monitor as a result of L-1's familiarity with the law being applied by L-O. Table 1 organizes these various relationships according to these three control mechanisms.

Each of the relationships in Case Studies \#\#1-4 enable L-1 to maintain control on the basis of an employment or partnership relationship with the lawyer receiving the referral, $\mathrm{L}-\mathrm{O}$. In these instances, $\mathrm{L}-1$ has the ability and incentive to train $\mathrm{L}-\mathrm{O}$ to perform according to her standards, based on the ongoing relationship among $\mathrm{L}-\mathrm{O}$ and $\mathrm{L}-1$ and her firm. Moreover, L-O's interest in maintaining his reputation with L-1 and within the firm generally supports the notion of control. This means that L-O will self-monitor for quality of work and timeliness, among other factors, so that even if L-1 cannot effectively review L-O's work product because $\mathrm{L}-\mathrm{O}$ must apply foreign law or expertise with which L-1 is unfamiliar or it is not cost-effective for $\mathrm{L}-1$ to supervise $\mathrm{L}-\mathrm{O}$ closely, L-1 nevertheless may trust that L-O will not exceed the boundaries of his competence. While temporary lawyers (Case Study \#4) do not share the same employment or partnership relationship with $\mathrm{L}-1$ as the other relationships described above, the temporary lawyer is likely to be motivated by the same reputational interests as lawyers in L-1's firm so that $\mathrm{L}-1$ will continue to hire him on a contract basis. ${ }^{86}$ In addition, physical proximity facilitates training for contract lawyers. Moreover, the employment and even quasi-employment relationships support the protection of confidentiality of client information. ${ }^{87}$

85. Such a referral may occur because L-1 or her firm is conflicted out of representing the client on the particular matter.

86. See Deger, supra note 37 (According to Thomas Sager, then chief litigation counsel at DuPont, "the temporary agency... uses many of the same lawyers repeatedly, so they have come to know and understand DuPont's methods").

87. Coster, supra note 26 (discussing the concern in outsourcing that two different firms will use the same group of lawyers in the offshore location and that client confidences will inadver- 
TABLE 1:

CASE Studies

\begin{tabular}{|c|c|c|c|c|}
\hline & $\begin{array}{l}\text { Mechanism of } \\
\text { control }\end{array}$ & $\begin{array}{c}\text { Employment or } \\
\text { partnership } \\
\text { relationship }\end{array}$ & $\begin{array}{l}\text { Physical } \\
\text { proximity }\end{array}$ & $\begin{array}{c}\text { Ability to } \\
\text { effectively } \\
\text { monitor } \\
\text { through shared } \\
\text { education/ } \\
\text { licensing }\end{array}$ \\
\hline \#1 & $\begin{array}{c}\text { Referred to another } \\
\text { lawyer in office }\end{array}$ & Yes & Yes & Yes \\
\hline \#2 & $\begin{array}{l}\text { Referred to lawyers } \\
\text { in branch office of } \\
\text { same law firm }\end{array}$ & Yes & No & \begin{tabular}{|l} 
Possibly \\
(depends \\
upon \\
whether \\
lawyers in \\
non-U.S. \\
offices are \\
U.S. lawyers) \\
\end{tabular} \\
\hline \#3 & $\mid \begin{array}{c}\text { Referred to non-U.S. } \\
\text { lawyers in } \\
\text { non-U.S. office of } \\
\text { same law firm }\end{array}$ & Yes & No & No \\
\hline \#4 & $\begin{array}{l}\text { Referred to a } \\
\text { temporary lawyer } \\
\text { (licensed in the } \\
\text { U.S.) hired by L-1 }\end{array}$ & No, but & Possibly & Yes \\
\hline \#5 & $\begin{array}{l}\text { Referred to lawyers } \\
\text { in different law } \\
\text { firm located in } \\
\text { same city as L-1 }\end{array}$ & No & No & Yes \\
\hline$\# 6$ & \begin{tabular}{|l|} 
Referred to an \\
outsourcing \\
intermediary firm \\
that will hire \\
non-U.S. lawyers \\
in non-U.S. \\
jurisdiction
\end{tabular} & No & No & $\begin{array}{l}\text { Yes (based on } \\
\text { outsourcing } \\
\text { firm's staff } \\
\text { being U.S. } \\
\text { licensed) }\end{array}$ \\
\hline$\# 7$ & $\begin{array}{l}\text { Referred to non-U.S. } \\
\text { lawyers working } \\
\text { for a different law } \\
\text { firm in non-U.S. } \\
\text { location }\end{array}$ & No & No & No \\
\hline
\end{tabular}

In contrast, the relationships in Case Studies \#5-7, including referrals to lawyers in different law firms regardless of their location and through outsourcing intermediaries, lack the same reputational connec-

tently be shared as a result. Orrick Herrington \& Sutcliff for example, uses contract lawyers but keeps them in the same location as the firm's permanent legal staff.). 
tion. Of course, reputation still matters; it is unlikely that L-1 would refer a matter to any lawyer without some knowledge or experience relating to the lawyer's abilities. But reputation requires information, and the relationships in Case Studies \#\#5-7 are less likely to lead to L-1's being as thoroughly familiar with L-O's work. ${ }^{88}$ Among Case Studies \#\#-7, the outsourcing example-Case Study \#6 - gives more opportunities for information that may lead to an assessment of ability than the other referral relationships described in Case Studies \#\#5 and 7. Generally, once a matter is referred out, as in Case Studies \# 5 and 7 , L-O would not return his work product to L-1. Rather, L-O likely will interact directly with the client. As a result, L-1 will need to rely on the client's assessment of L-O's services to formulate her opinion, and this may be somewhat awkward if $\mathrm{L}-\mathrm{O}$ is also a potential competitor of L-1 or her firm. In outsourcing, it is likely that $\mathrm{L}-\mathrm{O}$ will accomplish the outsourced tasks and return the work product to L-1, giving L-1 the ability to review the work upon completion of the project. Thus, outsourcing provides some measure of control by the referring attorney, $L-1$, that is absent in a typical referral relationship. Nevertheless, the efficiency of L-1's ability to monitor based on common education and expertise is necessarily limited both by the cost of L-1's time and the nature of the matter undertaken by $\mathrm{L}-\mathrm{O}$. The more detailed the review by L-1 of L-O's work product, the less savings afforded by referring the matter to $\mathrm{L}-\mathrm{O}$, since the cost of $\mathrm{L}-1$ 's time spent on reviewing the work will reduce the cost savings. ${ }^{89}$ On the other hand, even if L-1 reviews L-O's work carefully, it may be difficult for her to reach a conclusion about the advice offered by L-O if L-O's work relates to a sophisticated legal issue that is outside of L-1's area of expertise. Control through this mechanism of shared education and licensing may be illusory. As a Florida lawyer commented recently, "It's hard enough to assure quality work from people in your own firm let alone people you don't know who are located halfway around the world."90

Of course, lawyers may contract for control and the right to supervise outsourced work. L-1 and L-O might agree that $\mathrm{L}-\mathrm{O}$ will communicate with the client only through $\mathrm{L}-1$, that all work produced by $\mathrm{L}-\mathrm{O}$ be submitted to $L-1$ for review, and that the work be performed in a setting monitored by $\mathrm{L}-1$ for issues of access and other matters affecting the

88. Id. ("Many lawyers feel uncomfortable with the idea of outsourcing work to professionals who they've never trained, let alone met, yet whose work reflects the quality of the firm.").

89. See Blumenthal, supra note 49.

90. Braga, supra note 5 (quoting Doc Benjamin, a Williams Parker Harrison Dietz \& Getzen partner). 
ability to keep client information confidential. The retention of control in this manner increases the costs associated with outsourcing. In addition, depending upon the location of the outsourced work, the enforceability of the contract may be at issue..$^{91}$

\section{Focusing on Professional Ethics and Tort Liability}

\section{A. An Overview}

While the capability to offshore developed only recently, the principles of professional ethics and tort liability that constrain a lawyer's decision to send back-office and support functions, law-related services, or legal services ${ }^{92}$ to foreign lawyers or vendors are long standing. For example, a lawyer is generally under no obligation to inform a client that other lawyers and non-legal personnel within the lawyer's firm will be working on the client's matter. ${ }^{93}$ Thus, in Case Studies 1-3, supra, L-1 may proceed without advising the client of the involvement of L-1's associates, partners, or non-legal personnel.

In contrast, a lawyer must obtain a client's consent before associating

91. See, e.g., Emily Umbright, Appearing in St. Louis, Indian Advocate Provides a Legal Perspective on Outsourcing Work, St. Lous DaILY RECORD/St. Louis Countian, Aug. 23, 2005 (Indian law holds only the employer liable for breaches of confidentiality by leaks of information); Krebsbach, supra note 10 (describing efforts to strengthen enforcement of security breaches in India).

92. As discussed more fully, infra notes 114-16 and accompanying text, the line between legal services and law-related services is far from bright. This article adopts Model Rule 5.7(b)'s definition of the phrase, "law-related services":

services that might reasonably be performed in conjunction with and in substance are related to the provision of legal services, and that are not prohibited as the unauthorized practice of law when provided by a non-lawyer.

Model Rules of Prof'l Conduct R. 5.7(b) (2003). The Model Rules definition is singularly unhelpful in trying to decide whether a particular service is "legal" or "law-related." The Comment to the Rule provides some, but not much, guidance. Examples of law-related services include providing title insurance, financial planning, accounting, trust services, real estate counseling, legislative lobbying, economic analysis, social work, psychological counseling, tax preparation, and patent, medical or environmental consulting. $I d$. at R. 5.7 (b) $\mathrm{cmt}$.

93. The Comment to Model Rule 1.6 specifically notes:

Lawyers in a firm may, in the course of the firm's practice, disclose to each other information relating to a client of the firm, unless the client has instructed that particular information be confined to specified lawyers.

Id. at R. $1.6 \mathrm{cmt}$. 
with an outside lawyer. ${ }^{94}$ This well established principle applies equally to all of Case Study \#5 (a referral to lawyers in a different law firm located in the same city as L-1), Case Study \#7 (a referral to non-U.S. lawyers working for a different law firm in a non-U.S. location), and Case Study \#6 (a referral to an outsourcing intermediary that will hire non-U.S. lawyers in a non-U.S. jurisdiction) ${ }^{95} \mathrm{~A}$ similar logic seems to compel the conclusion that the lawyer should inform the client even if the work being sent to the offshore provider is only law-related (i.e., not "legal services") and is being sent to a foreign vendor rather than a foreign law firm. The need for such advisement is especially obvious if the offshored work involves confidential client information and/or there is any form of a financial relationship between the provider and the law firm. ${ }^{96}$

94. Restatement (ThIRD) OF THE LAW GOVERNing LAWYers, $\$ 14, \mathrm{cmt}$. h, at 132 (2000); id. § 21, cmt. e; Restatement (Second) of AgenCy, § 18 (1994); Ronald D. Rotunda \& John S. Dzienkowski, Legal Ethics-The LaWyer's Deskbook on Professional ResponsibIlity (2004-05 ed.).

95. William B. Dunn, a lawyer who outsources legal services, has commented that it is not necessary to advise the client provided that the referring lawyer closely supervises the receiving lawyer. Darshana T. Lele, Outsourcing of Legal Work is Growing but There's Still Little Ethics Guidance, ABA/BNA LaWyer's Manual on Prof'l Conduct Newsletter, June 15, 2005. His opinion is generally consistent with the advice contained in Formal Opinion 88-356 issued by the ABA Committee on Ethics and Professional Responsibility and the opinions of some state bar association ethics committees relating to the employment of temporary lawyers. Other committees disagree, calling for mandatory disclosure. E.g., Oliver v. Bd. of Governors, 779 S.W.2d 212, 216 (Ky. 1989). See generally ABA/BNA LaWyer's MANUAL ON Prof'L Conduct $91: 410$ (2006). In light of this disagreement, the authors maintain that non-disclosure remains a risky proposition with respect to a lawyer's ethical responsibilities and potential tort liability.

96. E.g., Estate of Re v. Kornstein Veisz \& Wexler, 958 F. Supp. 907 (S.D.N.Y. 1997) (finding a conflict of interest may exist if certain of the lawyers in Law Firm A that had represented the plaintiff in the underlying action were previously associated with Law Firm B, the law firm that was acting as counsel for the defendant in that action, and Law Firm A had regularly accepted referrals from Law Firm B).

The need for complete and accurate disclosure to a client concerning a law firm's recommendation of a vendor, such as a document management company, to respond to discovery requests is both a matter of ethics and managing client relationships. The strength of this proposition is powerfully illustrated by the adverse reaction of the Adelphia Communications Corp. (Adelphia) when it learned that the outside vendor that it had hired at the recommendation of the law firm that was representing it in a very complex bankruptcy proceeding and criminal investigation was partially owned by family members of the lawyers in the firm. Adelphi fired the law firm and the ensuing publicity damaged the law firm's reputation. Robert Frank \& Nathan Koppel, Boies Office Sent Clients to 3rd Firm with Family Ties, WALL ST.J., Oct. 11, 2005, at C1; Robert Frank, Adelphia, Boies Firm Agree to Split; Cable Company Asked Special Counsel to Quit Over Ties to a Contractor, WALL ST. J., Aug. 30, 2005, at A3; Jonathan D. Glater, A Lion of the Courtroom Hears His Critics Roar, N.Y. TIMES, 
A law firm or law department ${ }^{97}$ seeking guidance on the principles of professional ethics and tort liability that are likely to arise in a decision to offshore legal services should consult the canonical texts on professional conduct, e.g., the Restatements of both Agency and the Law Governing Lawyers, caselaw on negligent referrals and failures to monitor law firm employees, third-party organizations, and outside lawyers to whom referrals have been made, and the provisions of ethics codes that place a particular responsibility on lawyers to supervise the firm's lawyers, non-legal employees, and under certain circumstances, third-parties. ${ }^{98}$

As noted earlier, ${ }^{99}$ offshoring frequently raises the threshold issue of the unauthorized practice of law (UPL) because the work is being sent directly to foreign lawyers who are not authorized to practice law in the United States or to vendors outside the United States who employ the foreign lawyers and/or non-legal professionals. Resolving the UPL issue is next to impossible for two reasons. ${ }^{100}$ First, UPL jurisprudence

Sept. 22, 2005, at Cl; Anthony Lin, Boies Schiller Dogged by Claims of Conflict Document Company Angers a Former Client, NAT'L L.J., Sept. 19, 2005, at 6.

97. Rule 1.0 of the American Bar Association Model Rules of Professional Conduct defines "law firm" as denoting, inter alia, "lawyers employed in. . .the legal department of a corporation or other organization." MODEL Rules OF PROF'L CONDUCT R. 1.0 (2003). This article adopts the Rule 1.0 definition. References to a "law firm" include a legal department.

98. To date, only two bar association ethics committees have issued opinions regarding the offshoring of legal services. Ass'n of the Bar of the City of New York, Formal Op. 2006-3 (2006); San Diego County Bar Ass'n Op. 2007-01 (2007). Their analysis is consistent with the views expressed in this article. There are also other substantive law dangers that a firm should be aware of, such as the possibility that it might be considered a joint employer with an offshore vendor, exposing it to potential liability for the employment law violations of the offshore company or that its transfer of materials to an offshore company might violate a U.S. export law or the privacy laws of foreign jurisdictions. E.g., Sam Ramanujan \& Sandhya Jane, A Legal Perspective on Outsourcing and Offshoring, 8 J. AM. ACAD. OF Bus. 51, 52-54 (2006); Aaron J. Schindel \& Jeremy Mitman, Workers Abroad, Trouble at Home: Multinational Employers Face Growing Liability for Labor Violations of Overseas Suppliers, N.Y.S.B.A. INT'L Practicum, Spring 2006, at 40; see also Richard F.D. Corley \& Elizabeth L. McNaughton, Current Issues in Outsourcing Transactions: Canadian Privacy Laws, the Patriot Act and Other Considerations, N.Y.S.B.A. InT'L PRACTICUM, Autumn 2005, at 138; Scott C. Harris, Outsourcing, Offshoring, NAT'L L.J., Sept. 12, 2005, at 14; Judith A. Moldover, Outsourcing: Who's the Boss?, N.Y.L.J., Apr. 4, 2005, at 9.

99. See supra notes $27-37$.

100. This article consequently makes no attempt to define "legal services." While the offshoring of back office functions and law-related services does not raise UPL issues, it does raise other ethical and liability issues such as confidentiality, competence, and monitoring. See infra notes 118-46 and accompanying text. For a discussion of the ethical issues specifically raised by the outsourcing of back-office functions, see Tex. Comm. on Prof. Ethics Op. 560 (2005); N.C. State Bar Formal Ethics Op. 6 (2003); D.C. Bar Op. 304 (2001); Ill. St. Bar. Ass'n, Adv. Op. $90-23$ (1991). 
with respect to outsourcing to U.S.-licensed lawyers, to foreign lawyers who are physically present in the United States, ${ }^{101}$ and to domestic vendors $^{102}$ lacks coherence. Defining the activities that constitute UPL is the responsibility of the states, and they have not taken a uniform view. ${ }^{103}$ The efforts of the American Bar Association to assert a leadership role in the creation of a national norm have failed miserably. ${ }^{104}$

Second, neither the courts nor bar regulators currently display any interest in enforcing UPL prohibitions against organizations in analogous circumstances involving the outsourcing within the United States of services that are arguably legal in character. Legal research, ${ }^{105}$ brief writing, ${ }^{106}$ and discovery-related activities ${ }^{107}$ are regularly undertaken by vendors without any protest from courts or bar regulators. The likely, but generally unarticulated, justification for their passivity is that the law firms and legal departments that retain these organizations supervise them and bear a significant marketplace and reputational risk if the organizations' final product is sub par.

The courts and bar regulators view UPL enforcement fundamentally

See also Kathryn A. Thompson, Still the Boss: Firms Must Retain Supervision of Employees under Outsourcing Arrangement, 92 A.B.A. J. 26 (2006).

101. E.g., In re Roel, 144 N.E.2d 24 (N.Y. 1957) (affirming a finding of criminal contempt and the issuance of a preliminary injunction, restraining a Mexico-licensed lawyer physically located in New York from giving advice limited to the domestic relations law of Mexico to clients physically located in New York).

102. Outsourcing to domestic vendors raises UPL issues because both the courts and state bar ethics committees have concluded that organizations may not employ lawyers to provide legal services to the organizations' clients (as opposed to the organization itself). The prohibition allegedly rests on the proposition that lawyers employed by an organization are less likely to be able to exercise independence of professional judgment on behalf of the organization's clients than lawyers employed by law firms. History reveals, however, that the real purpose behind the prohibition was to protect solo practitioners and small firms from competition. See Bruce A. Green, The Disciplinary Restrictions on Multidisciplinary Practice: Their Derivation, Their Development, and Some Implications for the Core Values Debate, 83 MINN. L. REv. 1115, 1157-58 (2000).

103. See generally Mary C. Daly, Choosing Wise Men Wisely: the Risks and Rewards of Purchasing Legal Services from Lauyers in a Multidisciplinary Partnership, 13 GEO. J. LEGAL ETHICs 217, 248-52 (2000).

104. See American Bar ass'n, Report of the Task Force on the Model Definttion of the Practice of LaW $\$ 5$ (2004).

105. Legal research has been determined not to be the practice of law when it is undertaken by a licensed lawyer for the benefit of other lawyers and the legal research is provided through an entity separate from the lawyer's law firm. See, e.g., Supreme Court of Ohio Bd. of Commissioners on Grievances and Discipline, Op. $88-018$ (1988).

106. See, e.g., Robert J. Ambrogi, Outsourced Legal Writing: If It's Used With Caution, It Can Be a Lifesaver, NAT'L L.J., Mar. 17, 2003, at C4.

107. See, e.g., Litigation Support: a Special Report, LeGAL TiMES, Mar. 22, 2004, at 34-37. 
as a matter of consumer protection, generally focusing their limited resources on non-lawyers who mislead unsophisticated clients about the clients' rights in areas such as domestic relations, bankruptcy, real estate, etc. ${ }^{108}$ Lawyers are punished only when their failure to supervise their employees facilitates the employees' UPL activities ${ }^{109}$ or when the lawyers deliberately assist the UPL activities of affiliated organizations. ${ }^{110}$ Rarely are lawyers ever sanctioned for assisting an out-of-state lawyer in the practice of law in a jurisdiction in which the lawyer is not licensed. ${ }^{11}$

The prime consequence of this jurisprudential incoherence and regulatory restraint is that law firms, in deciding to offshore legal services, likely face few, if any, UPL hurdles as a practical matter. The courts and bar regulators will likely continue to look the other way

108. E.g., Cleveland Bar Ass'n v. Slavin, 62 Ohio Misc. 2d 570, 572 (Ohio Bd. Comm'rs on the Unauthorized Practice of Law 1993 (real estate)); Statewide Grievance Comm'n v. Harris, 683 A.2d 1362 (Conn. 1996) (domestic relations); Fla. Bar v. Davide, 702 So.2d 184 (Fl. 1997) (domestic relations and bankruptcy); Office of Disciplinary Counsel v. Doan, 77 Ohio St. 236 (Ohio 1996) (real estate).

109. E.g., Adams v. Ky. Bar Ass'n, 843 S.W.2d 898 (Ky. 1993); Mays v. Neal, 938 S.W.2d 830 (Ark. 1997); In re Castorena, 270 B.R. 504, 520 n.30 (Bankr. D. Idaho 2001); In re Konohia, 550 S.E.2d 318, 319 (S.C. 2001). See also Jay M. Zitter, Annotation, What Constitutes Unauthorized Practice of Law by Paralegal, 109 A.L.R.5th 275 (2005).

110. E.g., In re Rodkin, 798 N.Y.S.2d 430 (N.Y. App. Div. 2005); In re Flack, 33 P.3d 1281 (Kan. 2001) (disciplining a lawyer for failing to supervise non-lawyers in connection with estate planning); Fla. Bar v. Flowers, 672 So. 2d 526, 528 (Fla. 1996) (disciplining a lawyer for failure to supervise a non-lawyer immigration consultant who shared office space with the lawyer).

111. But see Office of Disciplinary Counsel v. Pavlik, 732 N.E.2d 985 (Ohio 2001) (disciplining an Ohio lawyer who assisted an Illinois lawyer in practicing law in Ohio). See also Ga. Formal Advisory Op. 05-10 (2006) (A Georgia lawyer who acts as local counsel may risk discipline for an out-of-state lawyer's discovery abuses under certain circumstances.) See generally Christine M. Guerci, Annotation, Vicarious Liability of Attorney for Acts of Associated Counsel, 35 A.L.R.5th 717 (1996 \& 2004 Supp.); David A. Gerregano, Annotation, What Constitutes “Unauthorized Practice of Law" by Out-of State Counsel, 83 A.L.R.5th 497 (2005). On occasion, the courts have effectively "disciplined" an out-of-state lawyer for UPL by imposing non-disciplinary sanctions. E.g., Birbrower, Montalbano, Condon \& Frank, P.C. v. Superior Court, 949 P.2d 1, 13 (Cal. 1998) (denying a New York law firm's request for fees for services that constituted the practice of law in California); Wellmore Coal Corp. v. Harman Mining Corp., 568 S.E.2d 671, 675 (Va. 2002) (dismissing a notice of appeal signed by an out-of-state lawyer). See generally Sarah Diane McShea, Disgorgement of Fees and the Unauthorized Practice of Law, 2002 ProF. LAw. 153 (2002). The Birbrower decision was in large measure the impetus for the establishment of the ABA Commission on Multijurisdictional Practice. At the Commission's urging, the ABA amended Model Rule 5.5, expanding the circumstances in which a lawyer could ethically practice law in a jurisdiction in which the lawyer was not licensed. 
provided that consumer protection interests are not implicated. ${ }^{112}$

For many years, the fear that non-lawyers would interfere with a lawyer's exercise of independent professional judgment prompted the disciplinary authorities, bar association ethics committees, and courts to use the threat of potential UPL charges to discourage lawyers from establishing a law-related business with a non-lawyer. They also disfavored law-related businesses even if singly owned by a lawyer, fearing confusion by clients as to the nature of the services being rendered and conflicts of interests caused by the lawyer's referral of clients to the law-related business. While neither fear has entirely dissipated, lawyers now may offer law-related services under certain circumstances pursuant to ABA Model Rule 5.7.113

Model Rule 5.7 may directly impact a law firm's decision to offshore both legal and law-related services. While it is difficult to obtain precise information concerning the frequency and extent to which law firms and legal departments are offshoring both types of services, news articles and interviews suggest that offshoring occurs more frequently

112. See generally American Bar Ass'N, 1999 Survey of Unauthorized Practice of Law Commitress (2000) (recognizing that enforcement is ineffective at best in stopping either the demand for, or the resulting existence of, non lawyer legal service providers). Such interests might become implicated if, for example, the offshoring involved debt collection work. See, e.g., Boyd v. Wexler, 275 F.3d 642 (7th Cir. 2001).

113. Model Rules of Prof'l CONDuCr R. 5.7 (2003). Rule 5.7 entitled "Responsibilities Regarding Law-Related Services" provides:

(a) A lawyer shall be subject to the Rules of Professional Conduct with respect to the provision of law-related services, as defined in paragraph (b), if the law-related services are provided:

(1) by the lawyer in circumstances that are not distinct from the lawyer's provision of legal services to clients; or

(2) in other circumstances by an entity controlled by the lawyer individually or with others if the lawyer fails to take reasonable measures to assure that a person obtaining the law-related services knows that the services are not legal services and that the protections of the client-lawyer relationship do not exist.

(b) The term 'law-related services' denotes services that might reasonably be performed in conjunction with and in substance are related to the provision of legal services, and that are not prohibited as unauthorized practice of law when provided by a non-lawyer.

Id. See also supra note 92. See generally Robert R. Keatinge, Multidimensional Practice in a World of Invincible Ignorance: MDP, MIP, and Ancillary Businesses after Enron, 44 ARIZ. L. REv. 717 (2002); Lowell J. Noteboom, Professions in Convergence: Taking the Next Step, 84 MINN. L. REv. 1359 (2000); Henry Gottlieb, Ancillary Businesses Let Law Firms Provide a Fuller Range of Services and Gamer Revenue Beyond Hourly Billing, N.J.L.J., July 18, 2005, at 1; Leigh Jones, Firms Not Minding Their Own Businesses, LeGAL INIELUIGENCER, June 22, 2005, at 1. 
in connection with intellectual property matters than with other areas of the law. ${ }^{114}$ Some law firms have gone so far as to establish ancillary businesses outside the United States to provide non-legal services to their own clients, other law firms, and non-clients. ${ }^{115}$ These law firms consequently face an additional, distinct challenge arising from Model Rule 5.7's ethical restraints on ancillary businesses. The fact that these businesses are conducted in foreign countries is irrelevant to the Rule's applicability. ${ }^{116}$

\section{B. The Ethical Duties of Supervision and Monitoring and Assaciated Tort Liability}

Many of the ethical principles governing the client-lawyer relationship and the common law principles determining a lawyer's tort liability to a client with respect to offshoring are rooted in Section 405 of the Restatement of the Law of Agency. It provides in relevant part:

(2) An agent is subject to liability to the principal if, having a duty to appoint or to supervise other agents, he has violated his duty through lack of care or otherwise in the appointment or supervision, and harm thereby results to the principal in a foreseeable manner. He is also subject to liability if he directs, permits or otherwise takes part in the improper conduct of other agents.

(3) An agent is subject to liability to a principal for the failure of

114. See Coster, supra note 26; Jeff Blumenthal, Region's IP Lawyers Consider Offshore Outsourcing, Del. L. WKLY., May 25, 2005; see also US Patent Errors Revealed, MANaGING INTELLECTUAL PROPERTY, Feb. 2006 (reporting on mistakes identified in 1,600 patents proofread by Intellevate).

115. See Coster, supra note 26.

116. Model Rules of Prof'L Conduct R. 8.5 (2003): Disciplinary Authority; Choice of Law provides in relevant part:

(a) Disciplinary Authority. A lawyer admitted to practice in this jurisdiction is subject to the disciplinary authority of this jurisdiction, regardless of where the lawyer's conduct occurs.

The comment to Rule 8.5 notes :

The choice of law provision applies to lawyers engaged in transnational practice, unless international law, treaties or other agreements between competent regulatory authorities in the affected jurisdictions provide otherwise.

Id. at R. $8.5 \mathrm{cmt}$. 


\section{another agent to perform a service which he and such other have jointly contracted to perform for the principal. ${ }^{117}$}

Applying Section 405 to a lawyer's decision to offshore legal services or law-related services is theoretically straightforward. The lawyer must exercise a duty of care in selecting and monitoring the offshore vendor. Section 405 does not, however, impose vicariously liability on the lawyer for the vendor's negligence.

\section{Issues of Professional Conduct}

\section{Rules $5.1^{118}$ and $5.3^{119}$ of the Model Rules of Professional Conduct}

117. Restatement (Second) OF THE LAW OF AGENCY $\$ 405$ (1958 \& Supp. 2004). Determining whether an individual or an entity is an agent, subagent, independent contractor, servant or joint venturer involves a complex analysis that is outside the scope of this article. See id. $\$ 1 \mathrm{cmt}$. e (describing the characteristics of an agent and independent contractor); id. $\S 5$ (defining subagents and subservants); id. $\$ 220$ (defining servant); Restatement (ThiRD) Of AGENCY $\$ 3.03$ cmt. e(2) (T.D. No. 2, 2001) (defining a joint venture). Such determinations frequently turn on factual data relating to the degree and kind of supervision exercised by a principal and/or agent.

Further complicating these determinations is the public policy question, whether and to what extent should the existence of an underlying client-lawyer relationship influence the application of the Restatement principles. Although an individual or entity retained by a lawyer to provide legal or law-related services to a client may be properly characterized as a servant, a subservant, a joint venturer, or an independent contractor for some purposes by the Restatement, a court may not treat that characterization as controlling in determining a lawyer's ethical responsibilities or tort liability. See infra note 162 and accompanying text, describing the non-delegable duties that a lawyer owes a client.

For the purposes of this article, it is assumed, unless otherwise noted, that the relationship between the referring law firm and the offshore party performing the service satisfies the legal criteria for the creation of an agency relationship that is derivative of the underlying attorneyclient relationship.

118. Rule 5.1 provides:

(a) A partner in a law firm, and a lawyer who individually or together with other lawyers possesses comparable managerial authority in a law firm, shall make reasonable efforts to ensure that the firm has in effect measures giving reasonable assurance that all lawyers in the firm conform to the Rules of Professional Conduct.

(b) A lawyer having direct supervisory authority over another lawyer shall make reasonable efforts to ensure that the other lawyer conforms to the Rules of Professional Conduct.

(c) A lawyer shall be responsible for another lawyer's violation of the Rules of Professional Conduct if:

(1) the lawyer orders or, with knowledge of the specific conduct, ratifies the conduct involved; or

(2) the lawyer is a partner or has comparable managerial authority in the law firm in which the other lawyer practices, or has direct supervisory authority over the other 
create three categories of ethical responsibilities. The first focuses on partners and lawyers who hold managerial responsibilities within a law firm. They must make reasonable efforts to ensure that the firm has in effect measures giving reasonable assurance that "all lawyers in the firm conform to the Rules of Professional Conduct" ${ }^{120}$ and that the conduct of a non-lawyer employed, retained or associated with a lawyer is "compatible with the professional obligations of the lawyer."121 The second focuses on lawyers who have direct supervisory authority over other lawyers and non-lawyers. ${ }^{122}$ Both sets of duties, like Section 405 of

lawyer, and knows of the conduct at a time when its consequences can be avoided or mitigated but fails to take reasonable remedial action.

Model Rules of Prof'l Conduct R. 5.1 (2003). See generally Thomas A. Kuczajda, Self Regulation, Socialization, and the Role of Model Rule 5.1, 12 GEo. J. LeGAL ETHICs 119 (1998); Robert R. Keatinge, The Floggings Will Continue Until Morale Improves: The Supervising Attorney and His or Her Firm, $39 \mathrm{~S}$. TEx. L. Rev. 279 (1998); Irwin D. Miller, Preventing Misconduct by Promoting the Ethics of Attorneys' Supervisory Duties, 70 Notre DaMe L. Rev. 259 (1994); Rachel Reiland, Note, The Duty to Supervise and Vicarious Liability: Why Law Firms, Supervising Attorneys and Associates Might Want to Take a Closer Look at Model Rules 5.1, 5.2, and 5.3, 14 GEO. J. LEGAL. ETHICs 1151 (2001).

119. Rule 5.3 provides:

With respect to a non-lawyer employed or retained by or associated with a lawyer:

(a) a partner, and a lawyer who individually or together with other lawyers possesses comparable managerial authority in a law firm shall make reasonable efforts to ensure that the firm has in effect measures giving reasonable assurance that the person's conduct is compatible with the professional obligations of the lawyer;

(b) a lawyer having direct supervisory authority over the non-lawyer shall make reasonable efforts to ensure that the person's conduct is compatible with the professional obligations of the lawyer; and

(c) a lawyer shall be responsible for conduct of such a person that would be a violation of the Rules of Professional Conduct if engaged in by a lawyer if:

(1) the lawyer orders or, with the knowledge of the specific conduct, ratifies the conduct involved; or

(2) the lawyer is a partner or has comparable managerial authority in the law firm in which the person is employed, or has direct supervisory authority over the person, and knows of the conduct at a time when its consequences can be avoided or mitigated but fails to take reasonable remedial action.

Model Rules of Prof'l Conduct R. 5.3 (2003). See also In re Opinion No. 24 of the Committee on the Unauthorized Practice of Law, 607 A.2d 962, 969 (N.J. 1992) (While a lawyer may delegate tasks to a paralegal, the lawyer must directly supervise the paralegal even if the paralegal is an "independent paralegal" not an employee of the lawyer).

120. Supra note 118 and accompanying text.

121. Supra note 119 and accompanying text.

122. Compare Model Rules of Prof'l Conduct R. 5.1(b) with Model Rules of Prof'L ConduCT R. 5.3(b) (both subsections employ parallel language and create similar duties). 
the Restatement of Agency, create supervisory responsibilities rather than vicarious responsibility. ${ }^{123}$ The third duty imposes direct liability on lawyers for conduct by non-lawyers that violates the Rules of Professional Conduct or other professional obligations of the lawyer. The lawyer incurs liability if she either ratifies wrongful conduct or fails to take reasonable remedial action. ${ }^{124}$ Particularly significant is the introductory language in Model Rule 5.3, "a non-lawyer employed or retained by or associated with a lawyer," because it shows the broad range of relationships for which the lawyer must assume ethical oversight. ${ }^{125}$ There is ample caselaw under Rules 5.1 and 5.3 disciplining lawyers ${ }^{126}$ for failing to properly supervise the work of associates ${ }^{127}$ and non-lawyer employees. ${ }^{128}$

Applied to the decision to offshore legal services, Model Rules 5.1 and 5.3 and the supporting caselaw clearly require a law firm to

123. American Bar Ass'n, A legislative History: The Development of the ABA Model Rules of Professional Conduct, 1982-1998 229 (1999). Furthermore, these supervisory ethical responsibilities exist "even if state law provides certain damage limitations or exclusions for the purpose of liability." ABA Comm. on Ethics and Profl Responsibility, Formal Op. 96-401 (1996) (emphasis added).

124. Compare Model Rules of Prof'l Conduct R. 5.1(c) with Model Rules of Prof'L CONDUCT R. 5.3(c) (both subsections employ parallel language and create similar duties).

125. E.g., In re Flack, 33 P.3d 1281, 1286 (Kan. 2001) (disciplining a lawyer for failing to supervise an estate planning company); Fla. Bar v. Flowers, 672 So. 2d 526, 527 (Fla. 1996) (disciplining a lawyer for failing to supervise an immigration consultant). See also Spencer v. Steinman, 179 F.R.D. 484, 492 (E.D. Pa. 1998) (sanctioning a lawyer for a violation of Rule 45 of the Federal Rules of Civil Procedure by a paralegal in the lawyer's office).

126. In New York and New Jersey, law firms-as well as lawyers-may be disciplined. E.g., In re Law Firm of Wilens \& Baker, 777 N.Y.S.3d 116 (N.Y. App. Div. 2004); In re Ravich, 715 A.2d 216 (1998), aff d, 754 A.2d 554 (N.J. 2000); In re Jacoby \& Meyers, 687 A.2d 1007 (N.J. 1997).

127. E.g., In re Yacavino, 494 A.2d 801, 803 (N.J. 1985) (criticizing a law firm's "sink or swim" policy towards associates); In re Saab, 547 N.E.2d 919, 922 (Mass. 1989) (disciplining a lawyer for assigning a domestic relations matter to an inexperienced associate whom the lawyer failed to supervise); Attorney Grievance Comm'n v. Ficker, 706 A.2d 1045, 1052 (Md. 1998) (disciplining a lawyer for assigning a difficult drunk driving case to a novice lawyer and assigning too many cases to too few lawyers); In re Moore, 494 S.E.2d 804, 807 (S.C. 1997) (disciplining a lawyer for discovery failures even though the responsibility for responding to discovery demands was an associate's); People v. Kusick, 2001 WL 1161113 (Colo. O.P.D.J. June 6, 2001). See generally Wilbur McCoy Otto, Identifying and Maintaining Lawyer Competence and Professionalism, 56 DEF. CoUNSEL J. 288 (1989).

128. In re Jayson, 772 N.Y.S.2d 769, 770 (N.Y. App. Div. 2003) (disciplining a lawyer who failed to supervise two non-lawyer employees, as a result of which the lawyer filed an incorrect Uncontested Matrimonial Checklist with a court); State v. Taylor, 4 P.3d 1242, 1252 (Okla. 2000) (disciplining a lawyer who failed to supervise an employee with respect to the proper handling of a client's funds). See generally Jay M. Zitter, Annotation, What Constitutes Unauthorized Practice of Law by Paralegah, 109 A.L.R.5th 275 (2005). 
implement a policy of instructing its offshore vendors and providers to conform to the ethical obligations of the Model Rules and to adopt practices and procedures to monitor their compliance. Without such policies, practices, and procedures firmly established, lawyers run the serious risk of discipline. ${ }^{129}$ It is impossible to describe the content of those policies, practices, and procedures with any precision given the little public knowledge that exists about the details of the working relationship between law firms and the offshore vendors of legal and law-related services. Certainly the starting place is the policies, practices, and procedures already in place for monitoring and supervising a firm's lawyers, non-lawyer personnel, and outside vendors. As explained in more detail below, ${ }^{130}$ however, it is highly unlikely that simply modifying existing policies and procedures will be sufficient in light of the significant differences in foreign legal systems and professional education.

In formulating the specific provisions of these policies, practices, and procedures, a law firm must focus at a minimum on three substantive ethical obligations: ${ }^{131}$ the duty to maintain confidentiality of client information, ${ }^{132}$ avoid conflicts of interest, ${ }^{133}$ and provide competent representation. ${ }^{134}$

\section{a. Duty of confidentiality}

Observance of the duty of confidentiality requires a law firm to take

129. See supra notes 126-128.

130. See infra notes 139-152 and accompanying text.

131. Depending upon the financial arrangement between the law firm and the vendor, the law firm may also need to address ethical issues relating to fees for legal services and the sharing of legal fees with a non-lawyer. For example, one lawyer who outsources projects to India has reported "I usually bill the clients a certain hourly rate and pay these folks a portion of that rate." Coster, supra note 26. Fee splitting with non-lawyers was a matter of particular concern when businesses first began to offer temporary lawyer services. E.g., Ass'n of the Bar of the City of New York Comm. on Prof'l Ethics and Judicial Ethics, Formal Op. 1989-2 (1989); Ass'n of the Bar of the City of New York Comm. on Profl Ethics and Judicial Ethics, Formal Ops. 1988-3 \& 1988-3A (1988); N.J. Sup. Ct. Advisory Comm. on Prof'l Ethics, Op. 632 (1989); Fla. State Bar Ass'n Comm. on Profl Ethics, Op. 88-12 (1988). As the use of temporary lawyers became more common, ethical inquiries shifted to the question whether and to what extent a law firm could charge a client a "markup fee" for the services of a temporary lawyer. E.g., D.C. Bar Ethics Comm., Op. 284 (1998). Because of the paucity of information on the fee arrangements between law firms and offshore vendors, this article does not address ethical issues relating to fees.

132. Model Rules of Prof'l Conduct R. 1.6 (2003).

133. Id. R. $1.7,1.8 \& 1.9$.

134. Id. R 1.1 . 
multiple affirmative measures to ensure that its offshore agents understand the scope of a U.S. lawyer's duty to preserve information relating to the representation of a client. Breeches of confidentiality not only violate the Model Rules of Professional Conduct ${ }^{135}$ but they are also the basis of tort liability. Lawyers have been held liable for both inadvertent ${ }^{136}$ and deliberate ${ }^{137}$ disclosures.

Establishing procedures and policies to protect offshored confidential information and prevent illegal conduct such as insider trading does not require law firms to reinvent the wheel. ${ }^{138}$ Rather, they can build on existing internal procedures and policies that already have been implemented to prevent violations of U.S. securities and other relevant law. ${ }^{139}$ Firms without existing procedures and policies will need to adopt similar measures.

Law firm procedures generally focus on securing documents containing confidential information. They include such measures as physically and electronically segregating them, severely limiting access to them, restricting their copying, tracking copies, shredding unnecessary copies, and inserting code names in the documents and filing systems to

135. See Okla. v. McGee, 48 P.3d 787, 792 (Okla. 2002) (disciplining a lawyer for failing to supervise his secretary who disclosed the confidential information of Client $A$ to Client $B$ ).

136. E.g., Thiery v. Bye, 597 N.W.2d 449, 455 (Wisc. Ct. App. 1999) (disclosure of client's confidential medical information); Kohn v. Schiappa, 656 A.2d 1322, 1323 (N.J. Super. Ct. Law Div. 1995) (disclosure of the identity of adopting parents to natural parents); In re Mandelman, 514 N.W.2d 11, 12 (Wisc. 1994) (disclosure of confidential information to non-affiliated lawyers).

137. See, e.g., Sherman v. Klopfer, 336 N.E.2d 219, 232 (IIl. App. Ct. 1975) (disclosure of allegedly improper accounting to the Internal Revenue Service); Tri-Growth Centre City, Ltd. v. Silldorf, Burdman, Suignan \& Eisenberg, 265 Cal.Rptr. 330, 337 (Cal. Ct. App. 1989) (disclosure of the timing of a client's bid for property); Lakoff v. Lionel Corp., 137 N.Y.S.2d 806, 808 (N.Y. Sup. Ct. 1955) (disclosure of a client's invention).

138. The Insider Trading and Securities Fraud Enforcement Act of 1988 (ITSFEA) mandates that broker-dealers and investment advisors "establish, maintain, and enforce written policies and procedures reasonably designed" to prevent insider trading. Pub. L. No. 100-704. While a law firm is neither a broker-dealer or investment advisor as defined by ITSFEA, the SEC has taken the position that a law firm has an affirmative obligation to protect material, non-public information. SEC REL. No. 34-13437, 11 SEC Docket 2231 (1977).

139. Despite a firm's best efforts, misconduct by lawyers and non-legal personnel is unavoidable. E.g., United States v. O'Hagan, 521 U.S. 642, 675 (1997). See also Phyllis Diamond, Two Plead Guilly to Insider Charges Involving Tips from Law Firm Secretary, 36 SEC. REG. \& LAW REP. 1104 (June 21, 2004); Crime: Former Lawyer at BioTech Concern Given Prison Term in Insider Case, 36 SEC. REG. \& LAW REP. 142 (Jan. 26, 2004); Joyce E. Cutler, Crime: Lauyer Pleads Guilty to Insider Charges Over Acquisition of Software Company, 33 SEc. Reg. \& LAW REP. 1311 (Sept. 17, 2001); Crime: IP Lawyer Sentenced After Pleading Guilty to Insider Trading, 33 SEC. REG. \& LAW REP. 1758 (Dec. 17, 2001). 
mask the identity of the clients and other parties. ${ }^{140}$ Law firm policies focus on individuals, regularly reminding both lawyers and non-lawyers of the critical importance of preserving the confidential information, the dangers of conversations about client matters outside the law firm, and the risks of disclosure by e-mail. ${ }^{141}$ The importance of these measures cannot be underestimated. Furthermore, while all foreign jurisdictions in the common- and civil-law traditions acknowledge a lawyer's duty to maintain client confidences in one form or another, the courts, the organized bar, and the informal professional culture of a foreign country's legal system may well shape the contours of that duty differently. China ${ }^{142}$ and the Islamic countries where the shari'a is adopted, ${ }^{143}$ for example, are certain to have radically different perspec-

140. See Ronald E. Mallen \& Jefrexy M. SMith, 2 Legal Malpractice $\$ 13.9$, at 334-35 (2007 ed.). See also Ronald E. Mallen \& Jefrekey M. Smith, 1 Legal Malpractice $§ 2.25$, at 240-48 (2007 ed.).

141. See 1 MALLEN \& SMITH, supra nte $140, \S 2.25$, at 240-48.

142. Law of the People's Republic of China on Lawyers, arts. 33-34, 35(2), 44(6)-(7) \& 51, available at http://en.chinacourt.org/public/detail.php?id=100 (last visited Mar. 3, 2006). It has been noted:

U.S. firms practicing in China. . .may encounter vastly different rules concerning client confidences. At one time, Beijing even sent orders to foreign law offices in China requiring quarterly reports on information usually considered confidential by American lawyers, such as "client lists, locations of projects under consideration, affiliations with Chinese law firms, business reference lists, and the value of deals in negotiations."

Mark I. Harrison \& Mary Gray Davidson, The Ethical Implications of Partnerships and Other Associations Involving American and Foreign Lauyers, 22 PENN. STATE INT'L L. REV. 639, 651 (2004) (citing Yujie Gu, Note, Entering the Chinese Legal Market: A Guide for American Lawyers Interested in Practicing Law in China, 48 Drake L. Rev. 173, 186-87 nn.147, 148 (1999)). See also Charles Chao Liu, Note and Comment, China's Lauyer System: Dawning upon the World through a Tortuous Process, 23 WHITTIER L. REv. 1037 (2002); Shanghai Bar Drafts First Local Code for Lawyers, http:/ /www.china.org.cn/English/ 2002/Jan/25205/htm.

143. Determining the scope of a lawyer's duty of confidentiality under the shari'a is not an easy task.

Although principles of the shari'a are largely consistent with U.S. standards of confidentiality, various interpretations of Islamic law will determine the acceptability of disclosure. In contrast to the maslaha mursalah concept, other principles of the shari'a arguably demand that a lawyer abide by a higher standard of duty in maintaining a client's confidentiality. In complex representation involving Islamic issues, lawyers operating under the Model Rules are charged with recognizing these higher standards. It is, therefore, important for the lawyer dealing with Islamic issues to consult with the client on the duty of confidentiality. Although difficult to imagine, a Muslim party or client may expect a higher degree of confidentiality than a lawyer is accustomed to. 
tives.

Law firms must be certain that their agents understand that the duty of confidentiality generally extends to all information even if it is a matter of public record ${ }^{144}$ and that the duty continues even when the engagement is over. On a practical level, a law firm may be obligated to examine the offshore agent's hiring practices to ensure that only reputable employees have access to confidential information and that adequate measures are in place to prevent both physical and electronic theft of the information. Even the vendor's recycling policies must be examined. ${ }^{145}$

It may also be necessary to investigate the substantive law of the country in which the legal services are being performed with regard to the duty of confidentiality. If services are performed on behalf of a global organization, that organization's property may be subject to judicial or administrative seizure in numerous countries. Thus, a law firm must consider the risk, if any, to confidential client information that would result if a disgruntled employee, customer, or creditor of the vendor instituted a lawsuit and sought to seize the organization's property within the jurisdiction (e.g., its papers and documents containing confidential information). The disclosure of confidential client information might also be an issue if a dispute arose between the law firm and vendor, and suit was brought in foreign jurisdiction where the work was performed. ${ }^{146}$ An evaluation of risk must also include an assessment of the efficiency and honesty of the jurisdiction's court system, since in certain countries the judiciary is notoriously slow and/or corrupt.

M. McCary, Bridging Ethical Borders: International Legal Ethics with an Islamic Perspective, 35 TEX. INT'L L.J. 289, 313 (2000) (footnotes omitted).

144. This consequence of the ethical duty of confidentiality is counter-intuitive to many U.S. lawyers. E.g., In re Anonymous, 654 N.E.2d 1128, 1129 (Ind. 1995) (sanctioning a lawyer for revealing information despite the fact that the information was "readily available from public sources and was not confidential in nature"); Ex parte Taylor Coal Co., 401 So. 2d 1, 8 (Ala. 1981) (even though a fact was disclosed in a court proceeding and therefore lost the protection of the attorney-client privilege, it was still a "secret" and could not be disclosed by client's former lawyer); Bar Ass'n of Nassau County, Op. 96-7 (1996) (a lawyer may not disclose the conviction of a former client, even though the conviction is a matter of public record). Like their U.S. counterparts, most foreign lawyers and offshore organizations are likely to find this consequence unsettling.

145. E.g., NYSBA Comm. on Prof'l Ethics, Formal Op. 641 (1993) (analyzing a lawyer's ethical responsibilities in complying with local recycling laws).

146. This possibility has also been a matter of concern for state bar association ethics committees with respect to the hiring of temporary lawyers from an agency. E.g., State Bar of Cali. Comm. on Profl Responsibility and Conduct, Formal Op. 1992-126 (1992). 


\section{b. Duty to avoid conflicts of interest}

The duty to avoid conflicts of interest presents an even greater challenge than the duty to protect confidential client information. While the admonition to avoid conflicts of interest is a regular feature of codes of professional conduct in both common and civil law countries, the interpretation of that admonition is far from uniform. ${ }^{147}$ It is not at all unreasonable to assume that foreign lawyers and organizations that employ foreign lawyers are generally insensitive to U.S.-style conflicts. Consequently, a law firm must take painstaking care to communicate the conflicts' standards that the foreign lawyer or offshore organization must apply. ${ }^{148}$ Bar association ethics committees have created an extensive jurisprudence regarding the application of conflict of interest ethics rules to affiliated lawyers and law firms. They have analyzed, for example, conflicts avoidance by temporary lawyers $^{149}$ and lawyers in an "of counsel" relationship. ${ }^{150}$ That jurisprudence is a likely template for identifying the conflicts dilemmas springing from the offshoring of legal services to foreign lawyers. Finally, ethics opinions specifically discussing the relational boundaries between U.S. and foreign lawyers should also generally contribute to shaping the nature and extent of the U.S. lawyers' involvement and supervision. ${ }^{151}$

147. See Mary C. Daly, The Dichotomy Between Standards and Rules: A New Way of Understanding the Differences in Perceptions of Lauyer Codes of Conduct by U.S. and Foreign Lauyers, 32 VAND. J. Transnat'L L. 1117, 1121-22 (1999).

148. Law firms have been disqualified for conflicts attributable to the experts they retained. E.g., Schairer v. Schairer, 745 N.Y.S.2d 410 (N.Y. Sup. Ct. 2002); see also Gibbs Properties Corp. v. CIGNA Corp., 196 F.R.D. 430, 437 (M.D. Fl. 2000); In re Bell Helicopter Textron, Inc., 87 S.W.3d 139, 145, 151 (Tex. App. 2002); Western Digital Corp. v. Superior Court, 71 Cal. Rptr. 2d 179, 189 (Cal. Ct. App. 1998). It is not at all inconceivable that a court might disqualify a law firm for a conflict attributable to the foreign lawyers employed by an offshore vendor that the law firm hired or by the simultaneous or successive work that the vendor was conducting for another law firm. Using a dedicated team can lessen the possibility of a conflict. See DuPont Legal Again Sets the Pace-OutsourcingJudgment-Based Tasks, Metropoltran CoRP. Counsel, Sept. 2006, at 59.

149. E.g., ABA Comm. on Ethics and Prof'l Responsibility, Formal Op. 88-356 (1988); New York City Bar Comm. on Prof'l and Judicial Ethics, Formal Ops. 1989-2, 1988-3 \& 1988-3-A (1988); State Bar of Cali. Comm. on Prof'l Responsibility and Conduct, Formal Op. 1992-126 (1992).

150. E.g., ABA Comm. on Ethics and Prof'1 Responsibility, Formal Op. $90-357$ (1990); New York City Bar Comm. on Profl and Judicial Ethics, Formal Op. 1996-8 (1996).

151. E.g., ABA Comm. on Ethics and Prof'l Responsibility, Formal Op. 01-423 (2001) (U.S.licensed lawyers may form a partnership with a foreign lawyer provided that the foreign lawyer is a member of a recognized legal profession in the foreign country and that the partnership complies with the applicable law); NYSBA Comm. on Prof'l Ethics, Op. 762 (2003) (New York law firm with a foreign office must ensure that the firm's compliance with the New York 


\section{c. Duty of competence}

The duty of competence requires a law firm to conduct two lines of inquiry. The first is directed to answering the fundamental question, does the foreign lawyer or offshore vendor possess the knowledge and skills necessary to carry out the client's objective. ${ }^{152}$ The second is directed to an assessment of the on-the-ground, day-in day-out, capability of the foreign lawyer or offshore vendor to deliver the promised service. Neglecting either line of inquiry is fraught with ethical and/or liability peril.

\section{Issues of Tort Liability}

The principles governing a lawyer's tort liability for the actions of another lawyer to whom legal work has been outsourced have become less certain in recent years. Traditionally, a law firm and its partners were vicariously liable for the malpractice of the firm's lawyers and non-lawyer employees. Consequently, if a partner "outsourced" an assignment for a client to an associate or another partner in the firm, the law firm and all its partners bore the risk that the associate or partner might negligently represent the client and expose the firm and all its partners to financial ruin. ${ }^{153}$ Examples of this issue are demonstrated by Case Studies \#\#1-3, supra. ${ }^{154}$ The physical location of the lawyer receiving the assignment (e.g., main office, U.S. branch office, or

Lawyer's Code of Professional Responsibility is not compromised by the substantive law obligations of the firm's foreign lawyers and their ethical obligations); NYSBA Comm. on Prof'l Ethics, Op. 658 (1994) (a lawyer licensed to practice in New York State may enter into a partnership with a lawyer licensed in Sweden provided that "the training and ethical standards applicable to the foreign lawyer are comparable to those of an American lawyer."). See also ABA Comm. on Ethics and Prof'l Responsibility, Formal Op. 94-388 (1994) (analyzing the ethical issues created by various types of affiliations among law firms).

152. For a detailed checklist on how to select and train a foreign lawyer or offshore vendor see Dianne Barasso \& Arpita Mukherjee, Understanding India: How to Choose and Groom Talented Legal Professionals, MeTropoltTAN CORP. CounSEL, Nov. 2006, at 56; Outsourcing to India: An In-House Counsel's Perspective, id. at 64. The duty of competence also includes an obligation to understand cultural and linguistic differences that can impede effective communication. Steve Garmhausen, 2 Firms Pioneer Legal Outsourcing, CraIN's N.Y. Bus., Sept. 11, 2006, at 22; see generally Ronald A. Brand, Professional Responsibility in a Transnational Transactions Practice, 17 J.L. \& CoM. 301, 328-34 (1998); Bryon S. Hollins, The Hazard: Practicing Outside Your Area, 84 A.B.A. J. 58 (1998); Emily S. Lassiter, Note, Liability for Referral of Attomeys, 24 J. LeGaL Prof. 465 (2000); Robert E. Lutz, Ethics and International Practice: A Guide to the Professional Responsibilities of Practitioners, 16 FORDHAM INT'L L.J. 53, 81-85 (1992/1993).

153. See Restatement (Third) Of THE Law Governing LaWYers $\$ 58$ (2000 \& 2005 Supp.).

154. Supra notes $83-87$ and accompanying text. 
foreign branch office) is irrelevant.

The principle of vicarious liability has weakened within the last twenty years, however, as the legislatures and the courts have permitted lawyers to organize as professional corporations, ${ }^{155}$ limited liability partnerships, ${ }^{156}$ and limited liability corporations. ${ }^{157}$ Nonetheless, it remains true as a general proposition that law firms and their principals remain subject to vicarious liability for the actions of their partners, ${ }^{158}$ associates, ${ }^{159}$ and non-lawyer employees ${ }^{160}$ that damage their clients. In some circumstances, they are liable for the acts of of-counsel attorneys ${ }^{161}$ and independent contractors who are performing nondelegable duties. ${ }^{162}$ Local counsel may also be liable to a client for the malpractice of an out-of-state lead attorney. ${ }^{163}$ There is at least one case suggesting that an associate may be liable to a supervising attorney for contribution arising out of the associate's negligence. ${ }^{164}$

The doctrine of vicarious liability becomes more complicated if the assignment is made to a lawyer who is not formally affiliated with the referring law firm, such as in Case Studies \#6-8, supra. In such instances, vicarious liability may be grounded on the non-delegable character of the responsibility being transferred to the receiving lawyer, the existence of a joint venture between the two lawyers, or the referring lawyer's failure to exercise due care in selecting the unaffiliated lawyer and/or in monitoring the lawyer's activities.

155. 1 MALLEN \& SMITH, supra note $140, \S 5.4$, at 560-71.

156. Id. $\$ 5.6$, at 584-99.

157. Id. $\$ 5.5$, at $571-84$.

158. Id. $\$ 5.3$, at 535-60.

159. E.g., Friesens, Inc. v. Larson, 438 N.W.2d 444 (Minn. Ct. App. 1989).

160. E.g., David C. Joel, Attorney at Law, P.C. v. Chastain, 562 S.E.2d 746 (Ga. Ct. App. 2002); Bullard v. Bailey, 959 P.2d 1122 (Wash. Ct. App. 1998).

161. E.g., Bankers Trust Co. v. Cerrato, Sweeney, Cohn, Stahl \& Vaccaro, 590 N.Y.S.2d 201 (N.Y. App. Div. 1992); Staron v. Weinstein, 701 A.2d 1325 (N.J. Super. Ct. App. Div. 1997). See also Restatement (THIRD) OF THE LAW GOVERNING LAWYERS $\$ 58 \mathrm{cmt}$. e (2000 \& Supp. 2005); 1 MALLEN \& SMITH, supra note $140, \S 5.7$, at 599-609.

162. E.g., Kleeman v. Rheingold, 614 N.E.2d 712 (N.Y. 1993). While a lawyer has wide latitude in the type of work that he may assign to a non-lawyer within his firm or an independent contractor, the courts have concluded that certain duties are non-delegable. They do not, however, agree on which duties fall within that category. Among the duties that are commonly described as non-delegable are: establishing the lawyer-client relationship; maintaining direct contact with a client; giving legal advice; and exercising legal judgment. See Nondelegable Duties, ABA/BNA LaWyer's Manual ON Prof'l Conduct 91:208 (2006).

163. Cf. Curb Records, Inc. v. Adams and Reese, L.L.P., 200 WL 9916932 (E.D. La. July 18, 2000); Streit v. Convington \& Crowe, Cal. Rptr.2d 193 (Ct. App. 2000).

164. Kramer v. Nowak, 908 F. Supp. 1281 (E.D. Pa. 1995). 
While state law defines the elements of a joint venture relationship, ${ }^{165}$ the most important characteristic for the purposes of this article is an agreement to share fees between the referring and receiving lawyer. ${ }^{166}$ In offshoring legal and law-related services, a law firm should consider how any financial arrangement between the lawyer and the vendor may impact a later claim that the vendor was not an independent contractor, but a joint venturer of the law firm, making the law firm vicariously responsible for the vendor's negligence.

Tormo $v$. Yormark ${ }^{167}$ is the touchstone for any discussion of vicarious liability involving a lawyer's referral of a matter to an out-of-state lawyer and consequently bears directly on a lawyer's decision to offshore law-related or legal services. In that case, a lawyer licensed to practice in New York referred a client with a potential personal injury claim to a lawyer in New Jersey. The New York lawyer did not research the New Jersey lawyer's competence or reputation for ethical behavior. He simply verified the lawyer's admission to the bar. Had he conducted a more complete investigation, he might have learned that the New Jersey lawyer had been indicted for conspiring fraudulently to obtain money from an insurance company. The New Jersey lawyer ultimately embezzled the funds received from the client's settlement of the personal injury claim. The client, in turn, sued the New York lawyer seeking to hold the lawyer vicariously liable for the embezzlement.

The court's opinion in Tormo is important for two reasons. First, it rejected on public policy grounds the client's argument that the New York lawyer had an independent obligation to conduct a comprehensive investigation into the character of the New Jersey lawyer. ${ }^{168}$ Second, it concluded that the New York lawyer could be held liable for the

165. RESTATEMENT (THIRD) OF THE LAW GOVERNing LAWYERS $§ 9 \mathrm{cmt}$. h (2000). A joint venture is treated as a form of a general partnership. According to the Restatement of Agency:

A general partnership results when two or more persons associate for the purpose of carrying on as co-owners a business for profit. ... General partnership is thus the legal structure applicable to an ongoing business that extends beyond a single project. An association limited to a single project is a joint venture. A joint venture is treated as a form of partnership, in which duties and authority are limited by the scope of the venture.

Restatement (THIRD) OF AGENCY $§ 3.03 \mathrm{cmt}$. e(2) (2006).

166. E.g., Armor v. Lantz, 535 S.E.2d 737, 744 (W. Va. 2000); Duggins v. Guardianship, 632 So. 2d 420, 426 (Miss. 1994).

167. 398 F. Supp. 1159 (D. N.J. 1975).

168. Id. at $1169-71$. 
embezzlement if the lawyer failed to make "such an inquiry as was required by ordinary prudence." ${ }^{169}$ The court denied the New York lawyer's motion for summary judgment except for the investigation claim because the pre-trial testimony of the lawyer, the client, and the client's father raised genuine issues of material fact with respect to whether the circumstances under which the referral was made triggered "such an inquiry as was required by ordinary prudence."

Tormo thus stands for the proposition that a lawyer may have some duty of inquiry before referring a client to another lawyer, especially one admitted in another jurisdiction. ${ }^{170}$ Its holding does not address the related question of the referring lawyer's vicarious liability for the negligence of the lawyer receiving the referral. The courts have almost uniformly rejected such a claim. ${ }^{171}$ The lesson to be learned from Tormo is simple. In making the decision to offshore back office, law-related, or legal services, a lawyer should make "such an inquiry as [is] required by ordinary prudence." The scope of that inquiry should reflect the sensitivity of the information and data being offshored. At a minimum, the lawyer will have to interview the prospective contracting party's business references thoroughly.

Prudence may call for a more exhaustive investigation of the foreign lawyer, law firm, or vendor that the lawyer is considering directly retaining or recommending that the client retain, if trade secrets, confidential client information, and work product are involved. In matters of extraordinary sensitivity, it may be necessary to hire an outside investigator to evaluate the prospective contracting party's professional integrity and competence.

169. Id. at 1171. Not all courts agree with Tormo. E.g., Bourke v. Kazaras, 746 A.2d 642 (Pa. Sup. Ct. 2000); Felker v. O'Connell, 1990 WL 31912 (E.D. Pa. Mar. 20, 1990). Whether any weight at all should be given to Bourke and Felker is highly questionable. To begin with, the Supreme Court of Pennsylvania has not addressed the issue of liability for a negligent referral. Furthermore, the courts' analysis was extremely terse and seemed to be heavily swayed by the prospect that the creation of such a cause of action might have an unfavorable impact on bar association referral services. See also Weisblatt v. Chicago Bar Ass'n, 684 N.E.2d 984, 989 (Ill. App. Ct. 1997); see generally Gonzales v. Am. Express Credit Corp., 733 N.E.2d 345, 351-53 (Ill. App. Ct. 2000).

170. See generally David A. Grossbaum, Watch Your Back of Referrals-Check Out the Other Attorney First, Then Put the Arrangement in Writing, 83 A.B.A. J. 86 (1997); Guerci, supra note 111; Andrew W. Martin, Jr., Comment, Legal Malpractice: Negligent Referral as a Cause of Action, 29 CuM. L. Rev. 679 (1998-1999).

171. E.g., Christensen, O'Connor, Garrison \& Havelka. v. State Dep't of Revenue, 649 P.2d 839, $842-43$ (Wash. 1982); Wilderman v. Wachtell, 267 N.Y.S. 840 (N.Y. Sup. Ct. 1933). See also Cohen v. Lipsig, 459 N.Y.S.2d 98, 98 (N.Y. App. Div. 1983) (among the issues of fact precluding summary judgment were "whether respondent used reasonable care in his choice of ... trial counsel. .. ."). See generally Guerci, supra note 111. 


\section{Conclusion: The Impact of Outsourcing on the Future Shape of THE Global Market fOR Legal SERVICES}

Professional regulation does not prevent offshore outsourcing but constrains it by requiring control and monitoring by U.S. lawyers. For GCs, offshore outsourcing is in many respects simply more of the same: instead of retaining their typical outside counsel for certain matters, they might outsource through an outsourcing intermediary or directly to non-U.S. lawyers working offshore. But referring work to the corporation's regular independent law firm and outsourcing to a foreign vendor generate entirely different consequences for the GC: the trust and confidence GCs typically place in the work of their outside counsel will be replaced by the need to monitor and review the work of the offshore outsourced worker. This monitoring function will reduce the cost savings from offshore outsourcing as well as require GCs to accept a more active and aggressive role. And while professional regulation requires monitoring in terms of the content of the advice, GCs also will need to be mindful of the impact of offshore outsourcing on their internal communication and control systems. ${ }^{172}$

The use of offshore outsourcing by corporate GCs adds a new element of competition for their typical outside counsel that may especially impact law firms that advise on more routine matters. In addition to outsourcing offshore, there is competition from non-law firms that specialize in particular substantive areas and whose staff may be comprised at least partly of lawyers, so that while the firm is not technically offering legal advice, the services offered reduce the use of outside counsel. ${ }^{173}$ These firms serve as real competition for lawyers, especially in the midsize law firm market, despite their being unable to market themselves as providing legal services as a result of the rejection and prohibition of multidisciplinary forms of organizations for lawyers. ${ }^{174}$ They operate as a sort of "stealth" multidisciplinary practice

172. Internal controls are the subject of disclosure and certification by the corporation and its auditors. See SEC Rule 13a-15, 17 C.F.R. $\$ 240.13 a-15$ (2005), adopted by the U.S. Securities and Exchange Commission pursuant to the Securities Exchange Act of 1934.

173. Joel A. Rose, Midsize Firms: Key Trends Affecting Competitiveness and Profitability, AccounTING FOR LAWYERS, Jan. 10, 2005, at 1.

174. Of course, professional regulation of lawyers is accomplished at the state level. See http://www.abanet.org/cpr/regulation/scpd/disciplinary.html for a listing of state agencies responsible for lawyer disciplinary matters. The District of Columbia's Rules of Professional Conduct authorize lawyers to share fees with non-lawyers under limited circumstances, pursuant to Rule 5.4. See http://www.dcbar.org/for_lawyers/ethics/legal_ethics/rules_of_professional_ conduct/Rule_five/rule05_04.cfm (last visited Apr. 29, 2006). But the American Bar Association 
firm.

'Stealth' MDPs are non-law professional service firms that offer services traditionally performed by lawyers through employees educated in the law. These services include corporate investigations, where the identification of material information is crucial, and tax advisory activities, where the clash between the accountants and lawyers traditionally has been waged. Entities offering business advice in other areas, such as mergers and acquisitions, environmental matters, or human resources, also employ law graduates and draw on their expertise. ${ }^{175}$

By sending work to non-U.S. lawyers working offshore as well as to those working in non-legal roles, ${ }^{176}$ corporate GCs avoid regulatory hurdles intended to protect the public from unqualified advisors. Their hiring of these advisers despite the regulatory problems may indicate their assessment that they do not need the protections offered by licensing regulations; instead, they may be comfortable judging competence and capability according to their own criteria and on the basis of their knowledge of the firms and lawyers.

For law firms considering whether to engage in offshore outsourcing themselves, different issues are relevant. The risk for law firms is that outsourcing will tarnish their reputations. This is particularly serious because the most efficient offshore outsourcing relationship will include only minimal time spent on supervision and training of the outsourced lawyers, and this raises concerns of quality control. In addition, outsourcing routine and low-stakes matters may hinder a firm's ability to provide sufficient training opportunities for its own new lawyers.

Law firms already employ significant numbers of lawyers who work offshore, and in many offices and firms the vast majority of these are

rejected a proposal to allow multidisciplinary practice in 2000. See materials at http:// www.abanet.org/cpr/mdp/home.html (last visited Apr. 29, 2006).

175. Bryant G. Garth \& Carole Silver, The MDP Challenge in the Context of Globalization, 52 CASE W. RES. L. REv. 903, 914 (2002) (footnotes omitted).

176. In fact, one report indicates that legal outsourcing firms are competing with the multinational accounting firms for law-related work. See Khozem Merchant \& Matthew Richards, Companies International: Outsourcing Has Found a New Field to Exploit, FIN. TMmes, Apr. 12, 2006, at 26 (reporting that legal outsourcing firm NewGalexy successfully attracted post-acquisition work on which Ernst \& Young also had bid). 
non-U.S. lawyers. ${ }^{177}$ But firms expect their foreign office lawyers to work on transactions at a similar level of sophistication to those performed by domestic lawyers in the firm. This organizational framework is irrelevant for outsourcing if the purpose is to lower legal fees. ${ }^{178}$

Law firms could, however, revise their structures to accommodate a sort of in-house outsourcing arrangement. One version might involve the organization of a second law firm, related through training and referral agreements, for example, which might function as a training firm for the primary firm in much the same way that minor league baseball teams offer training for players hoping to shift to the major league. The training firm would perform more routine services for significantly lower costs than the primary firm. ${ }^{179}$ As lawyers in the training firm became more experienced, one career trajectory would allow them access to the original, higher-end firm. Of course, this sort of sister-firm structure could be accomplished domestically, and it resembles the referral relationships that exist, at least informally, between top tier firms and others that occupy a lower rung on the prestige ladder, of which Lovell's "Mexican Wave" project is an example. ${ }^{180}$

Another possibility is that firms with international offices may see offshore outsourcing as an opportunity to develop relationships with local lawyers in jurisdictions otherwise closed to foreign firms, such as India, where the local rules prevent U.S. and other non-Indian firms from operating openly. When Indian regulations are liberalized, these firms may use their relationships to build their own offices, or bring the outsourcing workers "in-house."

177. Fewer than one-quarter of all lawyers working in the non-U.S. offices of 60 of the largest United States-based law firms earned the basic J.D. degree in a United States law school. See Silver, supra note 56 , at 926 .

178. U.S. firms already have geographically-based hierarchies in terms of compensation. See id. at 897. (describing compensation of lawyers in different offices of a single law firm as different, based on the law license of the individual).

179. A somewhat similar arrangement is described by Scott C. Harris in Outsourcing, Offshoring, NAT'L L. J., Sept. 12, 2005 (“Under the captive firm model [of offshoring], a U.S. firm opens a private office in, for example, India. Dedicated local managers are hired to train the local people. Everyone in the office works for the single firm. This requires a huge investment by the law firm opening the office, but in return provides the best offshoring service.").

180. Hodkinson, supra note 16. See Lovells, http://www.lovells.com/Lovells/OnlineServices/ MexicanWave/Mexican +Wave.htm ("Mexican-Wave is Lovells ground-breaking, award-winning outsourcing service that provides the highest quality work at the lowest possible cost. Lovells carries out the higher grade work whilst managing the outsourcing of the more routine work to a select group of provincial law firms (LSP).") (last visited April, 22 2007); Simon Leney, Private Client: A Helping Hand, LEGAL WK, Nov. 30, 2006. 
Whether offshore outsourcing will motivate law firms to reconsider their relationships with firms occupying different tiers in the legal market remains to be seen, but the attention devoted to offshore outsourcing in the legal and business press indicates its perception as a threat to the status quo. ${ }^{181}$ The states' rules of professional conduct and principles of tort liability will not prevent offshore outsourcing, although they may well render it less efficient. Rather, the competition for role of corporate adviser will be settled by the rules of the marketplace, including price, of course, but also quality and prestige.

In the realm of legal services, the importance of prestige and the relationships that status may support and engender, as well as the role of judgment and experience in the services offered, undermine to some extent the "flattening" impact of outsourcing. While there is no doubt that offshore outsourcing creates new opportunities for foreign lawyers, these opportunities do not put foreign lawyers on an equal footing with U.S. lawyers. Rather, they enable foreign lawyers to escape the strictures of their home legal professions. But there is an enormous space between finding new opportunities in the home jurisdiction market and gaining position in the U.S. market. Offshore outsourcing only emphasizes these divisions, which are characteristic of globalization generally. While we cannot predict the future, we see offshore outsourcing as one more factor contributing to the existing divisions in the legal market while simultaneously enabling shifting positions among the purchasers and sellers of those services.

181. There is also some indication that offshore outsourcing firms will enter the U.S. market to compete and cooperate more directly with U.S. law firms. See Richard J. Newman, Coming and Going, U.S. NEwS \& WORLD REPORT, Jan. 23, 2006, at 50 (reporting on Indian outsourcing firms establishing U.S. offices and hiring U.S. personnel). 
